\title{
Urban Resilience for Urban Sustainability: Concepts, Dimensions, and Perspectives
}

\author{
Xun Zeng ${ }^{1}$, Yuanchun Yu ${ }^{1, *}$, San Yang ${ }^{2}$, Yang Lv $^{3}$ (D) and Md Nazirul Islam Sarker ${ }^{4, *(D)}$ \\ 1 School of Management, Sichuan University of Science and Engineering, Zigong 643000, China; \\ zengxun@suse.edu.cn \\ 2 School of Public Affairs and Administration, University of Electronic Science and Technology of \\ China (UESTC), Chengdu 611731, China; kangiian@uestc.edu.cn \\ 3 College of Teachers, Chengdu University, Chengdu 610106, China; lvyang@cdu.edu.cn \\ 4 School of Political Science and Public Administration, Neijiang Normal University, Neijiang 641112, China \\ * Correspondence: yuanchun1981@suse.edu.cn (Y.Y.); sarker.scu@yahoo.com (M.N.I.S.)
}

check for updates

Citation: Zeng, X.; Yu, Y.; Yang, S.; Lv, Y.; Sarker, M.N.I. Urban Resilience for Urban Sustainability: Concepts,

Dimensions, and Perspectives. Sustainability 2022, 14, 2481. https:// doi.org/10.3390/su14052481

Academic Editor: Agnieszka Bieda

Received: 6 January 2022

Accepted: 18 February 2022

Published: 22 February 2022

Publisher's Note: MDPI stays neutral with regard to jurisdictional claims in published maps and institutional affiliations.

Copyright: (C) 2022 by the authors. Licensee MDPI, Basel, Switzerland. This article is an open access article distributed under the terms and conditions of the Creative Commons Attribution (CC BY) license (https:// creativecommons.org/licenses/by/ $4.0 /)$.

\begin{abstract}
Urbanization is a continuous process for a city's economic development. Though rapid urbanization provides a huge employment opportunity for people, urban threats also increase proportionately due to natural and man-made hazards. Understanding urban resilience and sustainability is an urgent matter to face hazards in the rapidly urbanized world. Therefore, this study aims to clarify the concept and develop key indications of urban resilience and sustainability from the existing literature. A systematic literature review guided by PRISMA has been conducted using literature from 1 January 2001 to 30 November 2021. It argues that sustainability and resilience are interrelated paradigms that emphasize a system's capacity to move toward desirable development paths. Resilience and sustainability are fundamentally concerned with preserving societal health and well-being within the context of a broader framework of environmental change. There are significant differences in their emphasis and time scales, particularly in the context of urbanization. This study has identified key indicators of urban resilience under three major components like adaptive capacity (education, health, food, and water), absorptive capacity (community support, urban green space, protective infrastructure, access to transport), and transformative capacity (communication technology, collaboration of multi-stakeholders, emergency services of government, community-oriented urban planning). This study also identified several indicators under major dimensions (social, economic, and environmental) of urban sustainability. The findings will be fruitful in understanding the dynamics of urban vulnerability and resilience and its measurement and management strategy from developed indicators.
\end{abstract}

Keywords: vulnerability; urban planning; sustainability; urban management; disaster management; resilience

\section{Introduction}

In the last few years, the rapid rate of urbanization has resulted in a massive rise in urban populations, infrastructure, and urban settings [1]. An urban area comprises citizen, settlements, and a built-environment [1]. More than $70 \%$ of the global population will live in cities by 2050, requiring trillions of dollars to update and improve infrastructure within a short period [1]. As a result of these changes, people become more vulnerable to climate variability and the costs of environmental damage. Climate change, which includes an increase in global temperature and the magnitude of extreme weather events, affects human populations and stresses the built environment [2]. Most recent climatic models predict that climate change will produce a diverse global impact, with the effects being more extreme in urban areas [3]. This is attributed to the increasing density of human beings, construction materials, and land-use patterns in the urban environment [4]. It is critical to understand how urban forms alter the climate locally and how climatic variability 
can significantly affect urban environments as the world's population shifts from villages to cities [5]. Short-term regular or monthly changes in temperature, precipitation, and wind within a given geographical area are important factors for understanding the vulnerability level in urban areas [6].

Rapid urbanization, urban regeneration, immigration, and economic cycles are only a few of the diverse factors that urban areas face [7]. Natural hazards add more complexity to the urban system. This is especially critical in cities in emerging economies experiencing rapid urbanization characterized by poor planning, weak institutional systems, and insufficient essential urban public services [8]. Due to a lack of capability, political will, or funding to combat climate change, preventive action is considered significant or feasible if it leads to changes in the quality of urban life. Failure to ensure basic services creates social and economic urban vulnerability, while natural hazards increase urban vulnerability and reduce urban resilience [9].

Resilience and sustainability are considered effective strategies to face any hazards and help the urban planning process [10]. Since sustainable development goals (SDG) viewed sustainability and resilience are inherently connected, scholar's understanding of these concepts is necessary to use in related fields [11]. Scholars have different opinions on the interrelationship, meanings, dimensions and perspectives of sustainability and resilience. For example, Redmen [12] mentioned that sustainability and resilience are complementary approaches, used interchangeably occasionally, and shared several principles. Zhang and $\mathrm{Li}$ [4] reported that urban resilience and sustainability focus on a city's vulnerability and tenacity, and meanings overlap, though overlapping weakens them. There are many variances in how resilience and sustainability are defined and used in the burgeoning literature. Miller [13] examined other approaches to sustainability. According to Brand and Jax [14], ambiguous and unclear interpretations impede scientific advancement since they are challenging concepts to apply. Wubneh [15] argued that both notions had acquired acceptance in urban planning as tools for assessing urban systems' resilience and adaptation. Therefore, it is necessary to understand both concepts properly for their effective use.

Sustainability has been widely applied to urban development from its origins in economics and ecological philosophy. Urban sustainability focuses on the persistence of a desirable outcome of urban environments over time [16]. It is frequently defined by aspects like intergenerational justice, intragenerational equity, natural resource protection, economic viability and diversity, societal self-sufficiency, social well-being, and fulfillment of fundamental human needs [17]. Sustainable development should be fair, livable, and economically feasible. The fact that sustainability possesses a weak conceptual framework [18], with unbalanced growth in the numerous facets of sustainability, most notably environmental issues, is considered a shortcoming. Many authors claim that sustainability changes depending on the researchers' research focus [19]. Turcu [20] argues that there is no globally acknowledged notion of sustainability. Sustainable development refers to longterm progress that meets human desires and improves their quality of life. Simultaneously, natural resources ought to be used in a frequency and degree that is compatible with the ecosystem's regenerative potential.

Sustainability is a broadly defined phrase $[17,19]$. The bottom line is ideally included in the wider notion; however, in practice, the concepts become more focused to encompass mostly environmental sustainability. Concerning "interpretation and application," sustainability is the most "difficult and controversial" problem, and when the phrase "sustainable" is combined with "development," the focus shifts to economical progress rather than total sustainability [21]. When nations prioritize economic expansion as the primary sustainable development goal, the earth's regenerative and carrying capacity is inevitably depleted. Because of the social effect on the idea of sustainability, its assessment becomes less objective, restricted to a specific scope, and subject to potential conflict of interest and management by stakeholders. Moldan et al. [22] argued that the essential pillar of sustainable development is social sustainability, but its definition is unclear. They wonder if it comprises rising or declining inequality between persons, communities, or 
nations, better health, or failure of state institutions. The triple bottom line, defined by Mori and Christodoulou [23] as a precise concept of biophysical, economic, and social components and intergenerational equity, are major concepts of sustainability. Sustainable development is a broader orientation for assessing and restructuring policies to improve urban management, not a precise description.

Resilience represents a system's ability to 'bounce back' or return to a previous stable condition after stressors caused by any hazard [24]. Resilience is also characterized as the urban community's ability to recover from the risks of hazards. Resilience is a city's or community's capacity to adjust, adapt, and, most importantly, changes in response to various internal and external hazards [25]. The urban community should have the capability of resilience thinking to help resolve environmental risks in the light of global environmental change. Many plans, programs, and initiatives have been undertaken in many cities to integrate sustainability into urban planning activities [26]. The resilience plan is advanced in urban management in many developed and developing nations. The Sustainable Development Goals (SDGs) specifically mention that cities should be 'inclusive, clean, resilient, and sustainable (SDG 11)'. Urban management is a critical element of global efforts to address disaster risk and adverse effects of climate change. New urban policies should focus on the concept of resilience [27]. Considering its importance, resilience has evolved into a discursive space to reflect the city and specific visions for its future.

Understanding the idea of urban resilience necessitates familiarity with the evolution of resilience theory [28]. Even though the term has been used in psychology, medicine, and engineering for a long time, it is widely credited to ecologist C.S. Holling in the literature regarding global environmental change. The capacity of an ecosystem to retain basic functional features to address disturbance is described by Holling [29]. The conception of socio-ecological system (SES) theory, led by a group of interdisciplinary ecologists, was the basis of the ecological framework of resilience and perception of ecosystems as dynamic, complex, and adaptive [28]. By conceptualizing nature-society as an interconnected, coevolving structure, SES theory essentially applied Holling's ecological principles to the 'social'. Resilience is also described as a combination of a system's ability to withstand perturbation without losing important functions or altering states, the system's potential to self-organize, and the ability for adaptation [30].

For empirical and theory-driven urban management studies, urban sustainability and resilience are emerging topics. In this context, scholars should investigate the use of traditional and novel regulatory tools, concepts, dimensions, contexts, and systems to govern urban sustainability and resilience. Surprisingly, however, regulatory experts have paid little attention to cities and the built environment in general [31].

The use of resilience and sustainability are growing rapidly in policy discourse due to their popularity. Weichselgartner and Kelman [32] argue that "While the academic debate on describing resilience continues, governments around the world have developed plans and programs that aim to guide cities, communities, and authorities towards achieving it." There is a wide range of possible interpretations of the phrases "urban sustainability" and "urban resilience" in terms of the possible pursuit of various environmental, economic, social, demo-graphic, and institutional goals [33]. It is also possible to accomplish these goals in other ways. In this way, the definitions of urban sustainability and resilience specify the kinds of activities that people may take and the degree to which they can either promote change or maintain the status quo [34]. Therefore, this study contributes to the debate by analyzing how both concepts are operationalized over time and context. This study breaks the perplexing status quo by clarifying their meanings, dimensions, and relationships.

It is now frequently observed that scholars tend to use 'resilience' and 'sustainability' terms in many irrelevant fields. This unrelated use creates a long-term misunderstanding of its genuine meaning and leads to misunderstanding. We think that the main reason for these misuses is a lack of proper understanding of these popularly used terms (resilience 
and sustainability). Existing literature shows that the urban management field is also not free from this challenge. An in-depth understanding of two research questions is necessary for using these concepts, like (a) does any relationship exist between urban resilience and sustainability, and (b) how can urban resilience promote urban sustainability? Therefore, this study intends to clarify the meaning of 'urban resilience and sustainability and the relationship between these concepts. The findings will help understand the dynamics of urban resilience and sustainability and its measurement and management strategy from developed indicators.

There are six sections in this study. Following the introduction in Section 1, Section 2 presents a detailed methodology including research design, research protocol, search strategy, inclusion and exclusion criteria. Section 3 deals with the obtained results. Section 4 presents the discussion focusing on concepts, dimensions, and urban sustainability and resilience perspectives. Section 5 discusses the conclusion, limitation, and future research direction.

\section{Materials and Methods}

The study has used preferred reporting items for the systematic review and metaanalysis (PRISMA) approach by developing a research protocol. PRISMA is a recognized evidence-based approach for systematic review and meta-analysis [35]. It comprises four major steps: identification, screening, eligibility, and inclusion. It also consists of 27 items checklist. The main benefits of using PRISMA are its structure and formatting, replicability, evaluation of strengths and weaknesses, and demonstration quality of document selection. All essential steps like research design, reasons for database selection, publication criteria, time duration, search strategy, search fields, inclusion and exclusion criteria have been presented chronologically.

\subsection{Research Design}

This study applied a mixed-method comprising systematic literature review to select the most relevant documents and a narrative review approach for explaining the key findings of the selected documents. This comprehensive analysis and synthesis entail the examination of a large and diverse body of literature on the subject and the integration and fusion of numerous academic, scientific, and technological domains. This review and synthesis are systematic because it was organized, defined, and conducted following PRISMA [35].

\subsection{Interdisciplinary Approach for Data Extraction}

Sustainable urban management is fundamentally interdisciplinary due to its technological and social sciences integration nature [36]. This applies to any interdisciplinary review because it incorporates insights and approaches from multiple disciplines into a single concept [37]. In this case, the chosen fields are urban management, planning, geography, sustainability, and environmental and computer science. Multidisciplinary efforts continue to have a limited effect on theory development for adapting to the changing conditions [38]. Research on urban resilience and sustainability necessitates multidisciplinary, interdisciplinary, and transdisciplinary perspectives and techniques [39]. All, however, require conceptual accuracy to ensure the validity and usability of the study findings.

\subsection{Development of a Research Protocol}

A research protocol was developed to guide the study scientifically (Table 1). A systematic review of the existing literature was conducted over the last 21 years. This study emphasizes the comparatively recent studies for arguments regarding the potential application of urban resilience (UR) concepts and practices for ensuring urban sustainability (US). 
Table 1. Details of the research protocol.

\begin{tabular}{cc}
\hline Items & Description \\
\hline Selected databases & Web of Science and Scopus \\
\hline Publication criteria & Only peer-reviewed journals \\
\hline Language & Articles published in English \\
\hline Time duration & From 1 January 2001 to 30 November 2021 \\
\hline Search terms & Urban resilience, city, sustainability, sustainable development \\
\hline Search fields & Title, abstract, and keywords \\
\hline Inclusion criteria & The study must focus on urban resilience and sustainability \\
\hline Exclusion criteria & $\begin{array}{c}\text { Unavailability of full text, duplication, and publication in a } \\
\text { non-English language. Additionally, papers that do not focus } \\
\text { on urban resilience and sustainability are omitted. }\end{array}$ \\
\hline
\end{tabular}

\subsection{Search Strategy}

Generally, literature reviews help develop a new field of research and education. They usually offer a chance to analyze, synthesize, and focus on previous studies to find new knowledge that can help develop a new paradigm of education and research. An extensive systematic review was conducted under the guidance of PRISMA [40]. Keeping these philosophies in mind, this study searched several widely used databases like the Web of Science and Scopus using a few keywords like urban resilience, urban management, and sustainability. The Web of Science and Scopus databases are well-accepted databases due to the quality selection of the articles and journals. Though there are many databases, all are not equally accepted, like Web of Science and Scopus databases. Not all related articles of other databases are included in these databases because of their qualitative selections. But all quality articles are indexed either in the Web of Science and Scopus databases. Therefore, this study selected these databases as a source. This study was conducted in November 2021. The following strategies strings were followed (Table 2).

Table 2. Search string and research databases.

\begin{tabular}{|c|c|c|}
\hline Databases & Search String & Time of Retrieval \\
\hline Web of science & $\mathrm{TS}=\left(\right.$ city $^{*}$ or urban resilien $\left.{ }^{*}\right)$ AND (urban sustain $\left.{ }^{*}\right)$ & 1 December 2021 \\
\hline Scopus & $\begin{array}{c}\text { ((TITLE-ABS-KEY }((“ \text { urban resilience”)) AND } \\
\text { TITLE-ABS-KEY ((“sustainability")) AND } \\
\text { TITLE-ABS-KEY ((“Concept”)))) AND ((urban AND } \\
\text { management)) AND (LIMIT-TO (DOCTYPE, “ar")) } \\
\text { AND (LIMIT-TO (LANGUAGE, “English”)) }\end{array}$ & 1 December 2021 \\
\hline
\end{tabular}

\subsection{Inclusion and Exclusion Criteria}

The predefined inclusion criteria were applied to select the most relevant documents, like (a) is the article highlighted on urban resilience and urban sustainability? and (b) is it focused on any relationship between urban resilience and sustainability? This study excludes articles published in a language other than English, no full text, or not exactly focusing on the desired issues.

\section{Results}

\subsection{Document Selection}

The PRISMA approach has four key steps such as identification, screening, eligibility, and included. The study followed these key steps. The most relevant documents were identified using PRISMA guidelines [40] (Appendix A). At the identification stage, 1569 documents were obtained from 2 core databases and 7 documents from the reference sources. A careful screening technique was followed at the second level, which helped 
remove 1252 unnecessary documents. Many records were excluded due to the unavailability of the full text or for being out of the field. In the eligibility step, 73 documents were removed because of the unavailability of intended information. Finally, the most relevant 49 papers were identified for a thorough review $[4,7,10-12,15,33,34,41-81]$. The documents were selected from journal articles for relevancy (Figure 1).

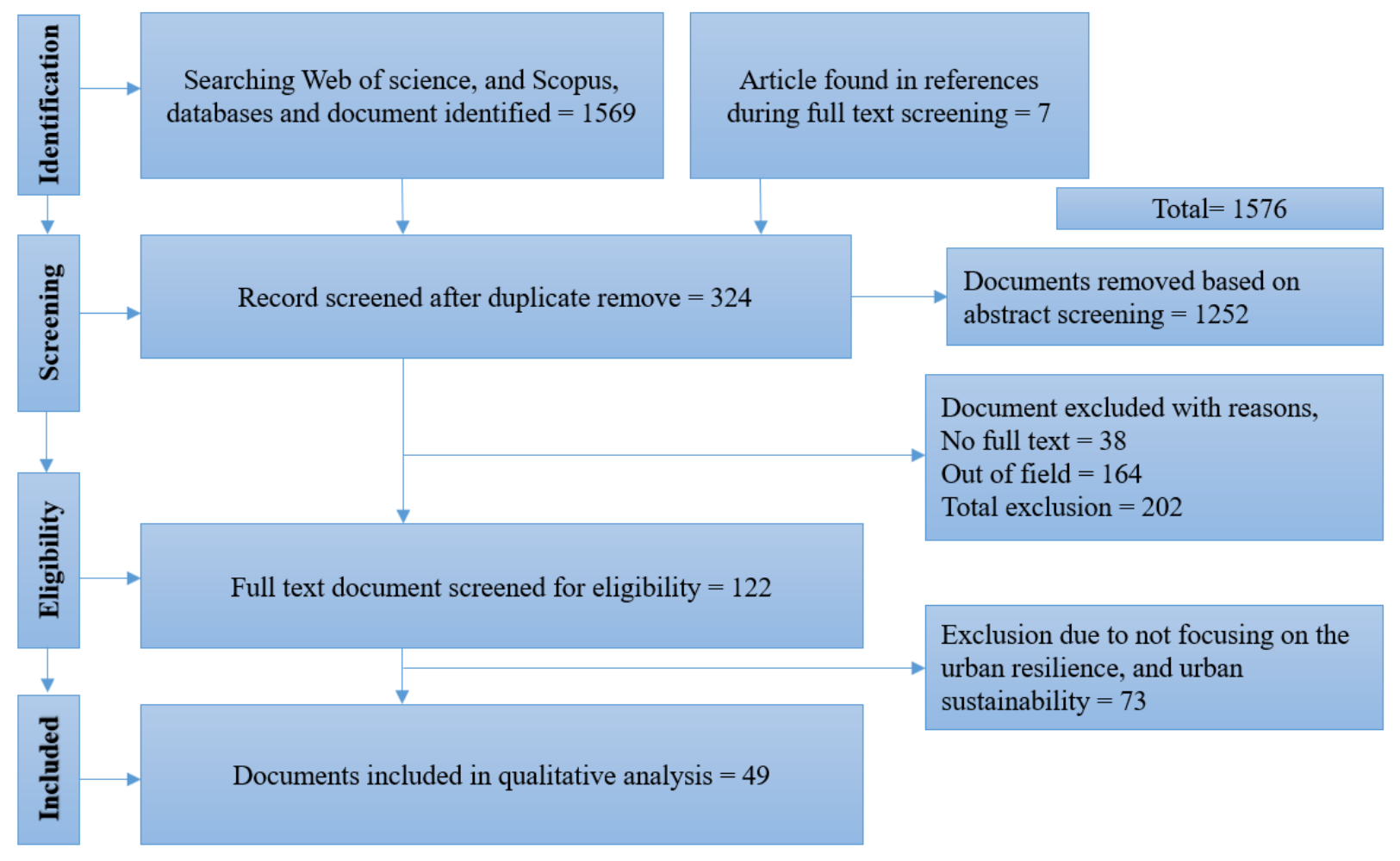

Figure 1. Document selection by PRISMA approach.

\subsection{Word Clouds of Urban Resilience and Sustainability}

The VOS viewer was used to create the word clouds [82]. When two papers share one or more references, bibliographic coupling occurs: the greater the overlap in references between two things, the more likely they are to belong to the same cluster. The VOS viewer creates a co-occurrence matrix, which shows a two-dimensional map of all the grouped elements based on their similarity measures. The stronger the links between the things reported in the matrix, the closer they are. This produces a cluster analysis, with groups understood as logical topics. An interpretive technique was used to organize clusters. Using these interpretations, a keyword analysis based on author keywords was used to investigate the most important issues covered in the scientific literature at the time. The purpose of generating a word cloud is to develop a concise picture of urban resilience and sustainability concepts and linkages among different related concepts. The phrases used most frequently in urban resilience and sustainability are depicted in Figure 2. The extracted articles' data demonstrate a minimum of five times co-occurrence of a term.

\subsection{Analytical Results}

Resilience and sustainability are multi-faceted notions that are applied to a variety of cases. The value-laden and contentious nature of the idea, which can be construed in various ways, is a major barrier that might derail the use of these concepts to guide planning activities. Resilience and sustainability are increasingly being recognized as a bridge concept that can promote inter- and transdisciplinary methods to dealing with the difficulties inherent in decision making under risk and uncertainty. As a result, it is vital to address the multiple components of resilience to improve human populations' capacity for adaptation. It is essential to understand dimensions to completely comprehend the 
interconnectedness and synergy of the many aspects of a problem [4]. Additionally, dimensions aim to align with the conventional understanding of resilience and sustainability [74]. Therefore, the study has identified the concepts, dimensions, and relationships between urban resilience and sustainability.

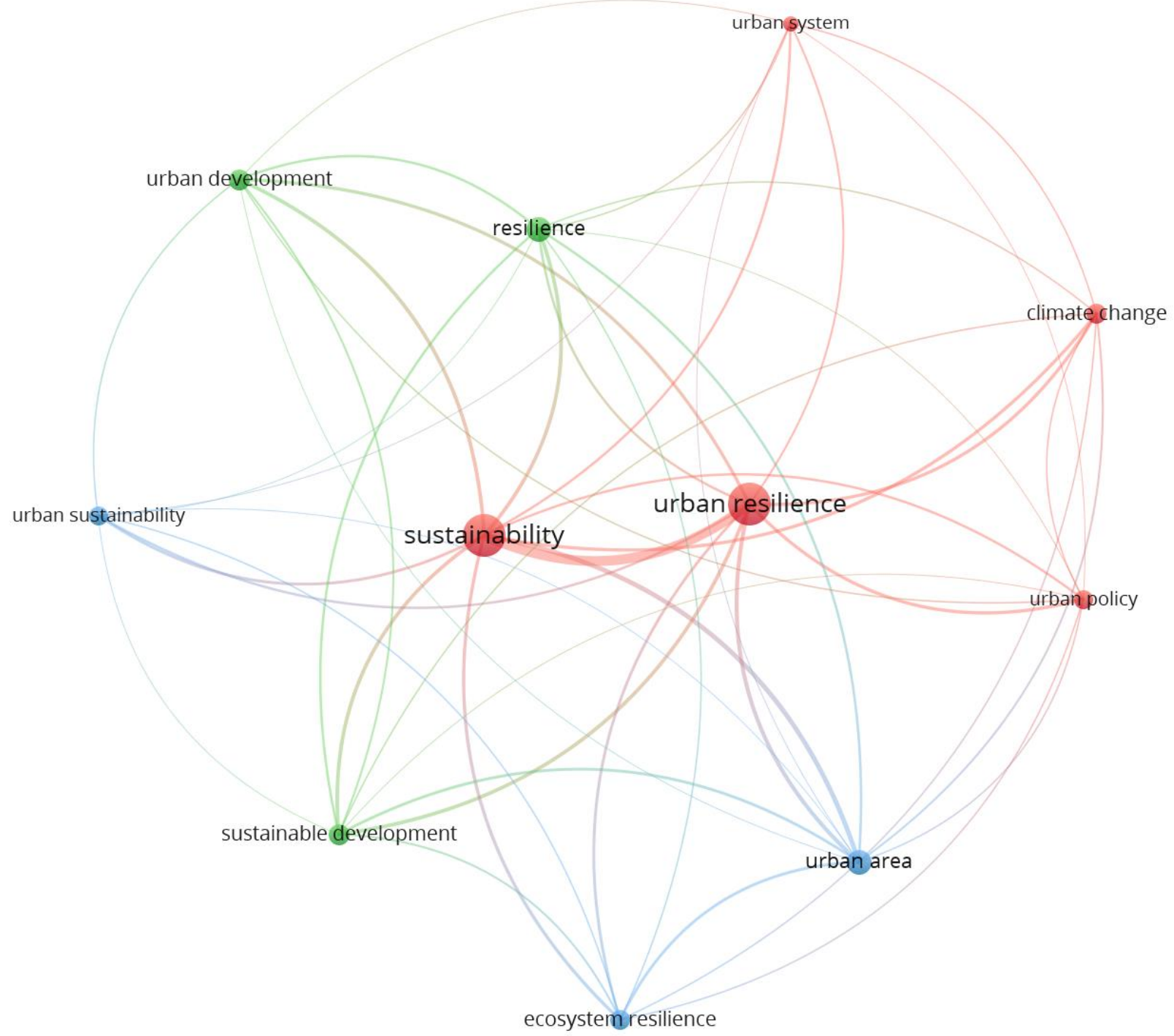

Figure 2. Word clouds of urban resilience and sustainability.

3.3.1. Summary of the Concepts

Summary of Urban Resilience Concept

The study has extracted the opinion of scholars on urban resilience concepts. The sources and key opinions have been summarized and presented in Table 3.

Table 3. Concepts of urban resilience.

\begin{tabular}{ccc}
\hline Sources & Time & Summary of Concepts \\
\hline Godschalk [83] & 2003 & $\begin{array}{c}\text { Resilience is a linkage of physical systems and human } \\
\text { societies that is self-sustaining. }\end{array}$ \\
\hline Pickett et al. [84] & 2004 & $\begin{array}{c}\text { Resilience is a system's capacity to adapt to } \\
\text { changing situations. }\end{array}$ \\
\hline Campanella [85] & 2006 & Resilience is a city's capacity to recover from disaster. \\
\hline
\end{tabular}


Table 3. Cont.

\begin{tabular}{|c|c|c|}
\hline Sources & Time & Summary of Concepts \\
\hline IPCC [86] & 2007 & $\begin{array}{l}\text { Resilience refers to a social or ecological system's potential } \\
\text { to absorb perturbations while keeping its essential } \\
\text { structure and modes of operation and its capacity for } \\
\text { self-organization and adaptation to stress and change. }\end{array}$ \\
\hline Alberti et al. [87] & 2008 & $\begin{array}{l}\text { The degree to which cities accept change before } \\
\text { reorganizing around a new set of structures and processes } \\
\text { is resilience. }\end{array}$ \\
\hline $\begin{array}{l}\text { Lamond and } \\
\text { Proverbs [88] }\end{array}$ & 2009 & $\begin{array}{l}\text { "encompasses the idea that towns and cities should be } \\
\text { able to recover quickly from major and minor disasters". }\end{array}$ \\
\hline Wardekker et al. [89] & 2010 & $\begin{array}{l}\text { "a system that can tolerate disturbances (events and } \\
\text { trends) through characteristics or measures that limit their } \\
\text { impacts, by reducing or counteracting the damage and } \\
\text { disruption, and allow the system to respond, recover, and } \\
\text { adapt quickly to such disturbances". }\end{array}$ \\
\hline Ernstson et al. [90] & 2010 & $\begin{array}{c}\text { "To sustain a certain dynamic regime, urban governance } \\
\text { also needs to build transformative capacity to face } \\
\text { uncertainty and change". }\end{array}$ \\
\hline Leichenko [91] & 2011 & $\begin{array}{l}\text { "the ability to withstand a wide array of shocks } \\
\text { and stresses". }\end{array}$ \\
\hline $\begin{array}{l}\text { Romero-Lankao and } \\
\text { Gnatz [92] }\end{array}$ & 2011 & $\begin{array}{c}\text { "a capacity of urban populations and systems to endure a } \\
\text { wide array of hazards and stresses". }\end{array}$ \\
\hline $\begin{array}{l}\text { Tyler and Moench } \\
\text { [93] }\end{array}$ & 2012 & $\begin{array}{l}\text { "encourages practitioners to consider innovation and } \\
\text { change to aid recovery from stresses and shocks that may } \\
\text { or may not be predictable". }\end{array}$ \\
\hline Liao [94] & 2012 & $\begin{array}{l}\text { "the capacity of the city to tolerate flooding and to } \\
\text { reorganize should physical damage and socio-economic } \\
\text { disruption occur, so as to prevent deaths and injuries and } \\
\text { maintain current socio-economic identity". }\end{array}$ \\
\hline Henstra [95] & 2012 & $\begin{array}{l}\text { "A climate-resilient city can withstand climate change } \\
\text { stresses, to respond effectively to climate-related hazards, } \\
\text { and to recover quickly from residual negative impacts". }\end{array}$ \\
\hline Wamsler et al. [96] & 2013 & $\begin{array}{l}\text { "A disaster-resilient city can be understood as a city that } \\
\text { has managed to: (a) reduce or avoid current and future } \\
\text { hazards; (b) reduce current and future susceptibility to } \\
\text { hazards; (c) establish functioning mechanisms and } \\
\text { structures for disaster response; (d) establish functioning } \\
\text { mechanisms and structures for disaster recovery". }\end{array}$ \\
\hline Coaffee [97] & 2013 & $\begin{array}{l}\text { "the capacity to withstand and rebound from } \\
\text { disruptive challenges". }\end{array}$ \\
\hline $\begin{array}{l}\text { Desouza and Flanery } \\
\qquad[98]\end{array}$ & 2013 & $\begin{array}{c}\text { "ability to absorb, adapt and respond to changes in } \\
\text { urban systems". }\end{array}$ \\
\hline Lu and Stead [99] & 2013 & $\begin{array}{l}\text { "the ability of a city to absorb disturbance while } \\
\text { maintaining its functions and structures". }\end{array}$ \\
\hline $\begin{array}{l}\text { Thornbush et al. } \\
\text { [100] }\end{array}$ & 2013 & $\begin{array}{l}\text { "a general quality of the city's social, economic, and } \\
\text { natural systems to be sufficiently future-proof". }\end{array}$ \\
\hline $\begin{array}{l}\text { Wagner and Breil } \\
\text { [101] }\end{array}$ & 2013 & $\begin{array}{l}\text { "the general capacity and ability of a community to } \\
\text { withstand stress, survive, adapt and bounce back from a } \\
\text { crisis or disaster and rapidly move on". }\end{array}$ \\
\hline
\end{tabular}


Table 3. Cont.

\begin{tabular}{|c|c|c|}
\hline Sources & Time & Summary of Concepts \\
\hline Wilson [102] & 2013 & $\begin{array}{l}\text { Community resilience is both an outcome, especially } \\
\text { when it comes to communities' better adaptive capacity, } \\
\text { and a process or pathway linked to dynamic changes } \\
\text { through time associated with community learning and } \\
\text { communities' determination to take charge of their own } \\
\text { development paths. }\end{array}$ \\
\hline ADB [103] & 2014 & $\begin{array}{l}\text { The ability of a city to function so that its citizens and } \\
\text { workers, particularly the poor and vulnerable, may } \\
\text { survive and develop regardless of the stressors or shocks } \\
\text { they confront is referred to as urban resilience. }\end{array}$ \\
\hline $\begin{array}{l}\text { Bahadur and } \\
\text { Thornton [104] }\end{array}$ & 2015 & $\begin{array}{c}\text { For urban resilience, decentralized decision-making, } \\
\text { systematic learning, interacting concurrently with } \\
\text { numerous shocks and pressures, proper urban planning, } \\
\text { and recognition of the political underpinnings of risk and } \\
\text { vulnerability are all required. }\end{array}$ \\
\hline HN-Habitat [105] & 2017 & 'Resilience is viewed as a process, a state, and a quality.' \\
\hline Zhang and Li [4] & 2018 & $\begin{array}{l}\text { Urban resilience refers to an urban actor's ability to cope } \\
\text { with or respond to hazard stress. Resistance refers to an } \\
\text { individual's or a group's ability to withstand the effects of } \\
\text { a threat in terms of their economic, psychological, and } \\
\text { physical well-being, as well as their maintenance systems. }\end{array}$ \\
\hline $\begin{array}{c}\text { Meerow and Newell } \\
{[34]}\end{array}$ & 2019 & $\begin{array}{l}\text { Urban resilience as a border entity and the capacity of } \\
\text { individuals, families, organizations, industries, and } \\
\text { structures within a city's ability to thrive, adapt, and } \\
\text { evolve regardless of the types of chronic stresses and } \\
\text { acute shocks they face. }\end{array}$ \\
\hline McGill [25] & 2020 & $\begin{array}{l}\text { The ability of an urban area to withstand disruption and } \\
\text { restore its conditions after a disturbance is known as } \\
\text { urban resilience. }\end{array}$ \\
\hline Bruzzone et al. [50] & 2021 & $\begin{array}{l}\text { An urban resilient community is capable of managing } \\
\text { unforeseen events and coping with pressures and shocks } \\
\text { while preserving and developing its social, economic, and } \\
\text { infrastructures systems. }\end{array}$ \\
\hline Wubneh [15] & 2021 & $\begin{array}{l}\text { The ability of an urban system to adapt and fully operate } \\
\text { in order to maintain its shape, structure, and identity in } \\
\text { the face of adversity is referred to as urban resilience. }\end{array}$ \\
\hline
\end{tabular}

\section{Summary of Urban Sustainability Concept}

The opinion of scholars on urban sustainability concepts has been extracted. The sources and critical views have been summarized and presented in Table 4.

\subsubsection{Dimensions of Urban Resilience and Sustainability Dimensions of Urban Resilience}

This study identified several indicators under each dimension. The key indicators under adaptive capacity are education, knowledge, skill, health, food, water, land, accommodation, training, inclusive access to credit and markets, social networks, ICT and technology, and legal and policy systems. Similarly, the key indicators under absorptive capacity are early warning system, community support, urban green space, protective infrastructure, access to transport, planning and framework development, united command development, determine ahead for each task, govern credit and resource distribution, human resource usage, utilization of equipment, and strengthen coverage of disaster management (Table 5). 
The key indicators under the transformative capacity are communication technology, a collaboration of multi-stakeholder, emergency services of government, community-oriented urban planning, monitoring expenses, human resources, and equipment quality monitoring, quality assurance, ensuring coordination, safety promotion, shared facilities of natural resources, community cooperatives / club, inclusive governance for sharing benefits, equal access to community resources, and citizen engagement in the policy process.

Table 4. Concepts of urban sustainability.

\begin{tabular}{cc}
\hline Sources & Summary of Concepts \\
\hline Eastaway and Støa [106] & $\begin{array}{c}\text { The perception of sustainability as applied to a city in the } \\
\text { metropolitan area's capacity and its region to continue to work at } \\
\text { standards of quality of people's life desired by the population } \\
\text { without reducing current and future generations' options or having } \\
\text { adverse impacts both inside and outside the urban boundary. }\end{array}$ \\
\hline $\begin{array}{c}\text { The word "sustainable city" has many definitions, and it includes or } \\
\text { is connected with several other, often contradictory, conceptual } \\
\text { designations. They attempt to balance economic progress, life quality, } \\
\text { and environmental sustainability. }\end{array}$ \\
\hline Verma and Raghubanshi \\
[108] & $\begin{array}{r}\text { Urban sustainability is a cross-cutting topic that affects the climate, } \\
\text { culture, and economy. }\end{array}$ \\
\hline Wu [109] & $\begin{array}{c}\text { Urban sustainability is a vital adaptive mechanism that promotes and } \\
\text { preserves a worthy cycle between ecological resources and people's } \\
\text { well-being by coordinating ecological, economic, and social activities } \\
\text { for changes within and outside the urban landscape. }\end{array}$ \\
\hline Russo and Cirella [110] & $\begin{array}{r}\text { Ecosystem services are vital for urban sustainability, and they have a } \\
\text { direct influence city quality of life. }\end{array}$ \\
\hline
\end{tabular}

Table 5. Major indicators of urban resilience.

\begin{tabular}{|c|c|c|}
\hline $\begin{array}{c}\text { Major } \\
\text { Dimensions }\end{array}$ & Major Indicators & Researchers and Time \\
\hline \multirow{10}{*}{$\begin{array}{l}\text { Adaptive } \\
\text { capacity }\end{array}$} & Food & Moench [111] \\
\hline & Water & Chelleri et al. [53] \\
\hline & Land & Cobbinah [112] \\
\hline & Education, Knowledge, Skill & Meerow and Stults [28] \\
\hline & Health & Leitner et al. [113] \\
\hline & Accommodation & Davoudi et al. [114] \\
\hline & Training & Malone [115] \\
\hline & Inclusive access to credit and market & Panampitiya [116] \\
\hline & Social networks & McGill [16] \\
\hline & Access to ICT and technology & Davoudi et al. [114] \\
\hline \multirow{13}{*}{$\begin{array}{l}\text { Absorptive } \\
\text { capacity }\end{array}$} & Access to transport & Ernstson et al. [90] \\
\hline & Planning and framework development & Ribeiro and Gonçalves [117] \\
\hline & United command development & Molavi [118] \\
\hline & Determine ahead for each task & Ribeiro and Gonçalves [117] \\
\hline & Early warning system & Brown et al. [119] \\
\hline & Community support & Molavi [118] \\
\hline & Urban green space & Meerow and Newell [34] \\
\hline & Protective infrastructure & Reischl et al. [120] \\
\hline & Govern credit and resource distribution & Nagenborg [121] \\
\hline & Human resource usage, & Moench [111] \\
\hline & Strengthen coverage of disaster management & Chelleri et al. [53] \\
\hline & Utilization of equipment, & Cobbinah [112] \\
\hline & Access to legal and policy system & Sarker et al. [8] \\
\hline
\end{tabular}


Table 5. Cont.

\begin{tabular}{ccc}
\hline $\begin{array}{c}\text { Major } \\
\text { Dimensions }\end{array}$ & Major Indicators & Researchers and Time \\
\hline & Coordination of works of multi-stakeholder & \\
Communication technology & Ribeiro and Gonçalves [117] \\
Collaboration of multi-stakeholder & Frantzeskaki et al. [122] \\
& Emergency services of government & Kim \& Lim [123] \\
& Community-oriented urban planning & Godschalk [83] \\
Mransformative & Monitoring expenses & Chelleri and Baravikova [52] \\
capacity & Human resources and equipment Quality & Heinzlef and Serre [124] \\
& Quality assurance & Fang et al. [125] \\
& Safety promotion & Ciumasu [126] \\
& Shared facilities of natural resources & Sharifi et al. [74] \\
& Inclusive governance for sharing benefits & Carter et al. [127] \\
& Equal access to community resources & Bahadur and Tanner [128] \\
& Citizen engagement in policy process & Ribeiro and Gonçalves [117] \\
& Community cooperatives/club & \\
\hline
\end{tabular}

Dimensions of Urban Sustainability

The major dimensions of urban sustainability are environmental, economic, and social. Each dimension focuses on several indicators that can represent the status of the specific dimension (Table 6). Indicators are essential at all stages of achieving results-oriented assessment. It helps to know the current status to provide a basis for measuring environmental, economic, and social change. By informing policymakers and the general public about the present condition of the environment, its strengths and weaknesses, and defining priority areas, indicators help achieve sustainability goals [129]. The indicators help validate a framework while also offering insight into the examined phenomenon. Simple indicators take individual phenomena like the number of poor people or the percentage of land covered by trees and combine them into a composite index based on the constituent indicators' weighting [130]. It helps evaluate, review, and implement sustainable practices and formulate public awareness policies [109]. Metrics can help policymakers make informed decisions, and results must be reported without ambiguity [131]. Sustainability indicators can serve as a benchmark for comparing current and baseline conditions [132]. They reflect policy measures, particularly for whom such measures can be implemented. As a result, indicators with political support are more likely to succeed and be accepted.

Table 6. Major indicators of urban sustainability.

\begin{tabular}{ccc}
\hline $\begin{array}{c}\text { Major } \\
\text { Dimensions }\end{array}$ & Major Indicators & Researchers and Time \\
\hline & Freshwater availability & Maurya et al. [133] \\
& Fresh air availability & Magee et al. [134] \\
& Renewable energy & Bibri [135] \\
Green space & Kong et al. [136] \\
Environmental & Waste management & Zhang et al. [137] \\
dimension & Community forestry & Allen et al. [138] \\
& Recycling of waste & Haapio [139] \\
& Green product & Reisi et al. [140] \\
& Green transport & Wu [109] \\
& Ecological footprint & Bibri [36] \\
& Mixed land use & Zhang and Li [4] \\
\hline
\end{tabular}


Table 6. Cont.

\begin{tabular}{|c|c|c|}
\hline $\begin{array}{c}\text { Major } \\
\text { Dimensions }\end{array}$ & Major Indicators & Researchers and Time \\
\hline $\begin{array}{l}\text { Economic } \\
\text { dimension }\end{array}$ & $\begin{array}{c}\text { Strategy for green development } \\
\text { Zoning } \\
\text { Tax policy } \\
\text { Green business } \\
\text { Urban growth } \\
\text { Labor and welfare } \\
\text { Green banking } \\
\text { Production and resourcing } \\
\text { Job opportunity }\end{array}$ & $\begin{array}{c}\text { Russo and Cirella [110] } \\
\text { Allen et al. [138] } \\
\text { Verma and Raghubanshi [108] } \\
\text { Bibri [36] } \\
\text { Liang et al. [141] } \\
\text { Pan et al. [142] } \\
\text { Kong et al. [136] } \\
\text { Haapio [139] } \\
\text { Anejionu et al. [143] }\end{array}$ \\
\hline $\begin{array}{c}\text { Social } \\
\text { dimension }\end{array}$ & $\begin{array}{c}\text { Social equity } \\
\text { Community garden } \\
\text { Accommodation } \\
\text { Social inclusion } \\
\text { Safety net program } \\
\text { Citizen participation } \\
\text { Homeless caring program } \\
\text { Food and nutrition system } \\
\text { Social insurance }\end{array}$ & $\begin{array}{c}\text { Bibri [36]; Ilieva and McPhearson [144] } \\
\text { Schwegler [107] } \\
\text { Kong et al. [136] } \\
\text { Zhang and He [145] } \\
\text { Ahvenniemi et al. [132] } \\
\text { Allen et al. [138] } \\
\text { Andronie et al. [146] } \\
\text { Huang and Wang [147]; Pan et al. [142] }\end{array}$ \\
\hline
\end{tabular}

\subsubsection{Relationship between Urban Resilience and Sustainability}

The relationship between resilience and sustainability is sometimes misunderstood conceptually [12] (Table 7). In some contexts, the terms sustainability and resilience can be applied interchangeably. Resilience is also considered a major element of wider sustainability goals. It also has been praised as a new and better paradigm. According to leading resilience scholars, system resilience is critical for attaining sustainability in "a world of transitions" [148]. Thus, as a vivid concept, resilience has no conflict with sustainability. Despite their disparate theoretical foundation, there are essential distinctions when understood as a paradigm for environmental transformation and management.

Resilience places a premium on system-based modeling and analyzes SESs as the fundamental unit of evaluation. This can obscure systemic disparities, overlook the diversity of social players engaged, and provide little focus on social dynamics. There is a considerable emphasis on balancing economic, environmental, and social justice goals in the sustainability literature. Such themes receive little attention in resilience studies [149]. In some cases, such as sustainability and resilience, these concepts are interchangeable. In other instances, these are inversely associated, with resilience viewed as the polar opposite of vulnerability or perhaps one of its determinants [150].

Table 7. Summary of the scholar's opinion about nexus between UR and US.

\begin{tabular}{ccc}
\hline Summary of the Opinion & Time & Sources \\
\hline $\begin{array}{c}\text { Obtaining resilient sustainability will need considerable } \\
\text { technological advancements. Addressing the sustainability and } \\
\text { resilience concerns, perhaps, will demand a transdisciplinary and } \\
\text { integrative approach to sustainability. }\end{array}$ & 2011 & Ahern [44] \\
\hline $\begin{array}{c}\text { Numerous cities have begun to apply the concepts of urban } \\
\text { resilience and sustainability to specific places. However, urban } \\
\text { resilience and sustainability are not location-specific but rather refer } \\
\text { to whole systems—open systems comprised of a diverse variety of } \\
\text { resources, assets, and knowledge fluxes. The connections may be } \\
\text { rather intricate, and the feedback systems can be indirect. }\end{array}$ & 2014 & Elmqvist [151] \\
\hline $\begin{array}{c}\text { Urban sustainability is a slightly more developed idea, and its } \\
\text { conceptualizations generally include at least three distinct types of } \\
\text { urban dynamics. }\end{array}$ & 2016 & Trundle et al. \\
\hline
\end{tabular}


Table 7. Cont.

\begin{tabular}{|c|c|c|}
\hline Summary of the Opinion & Time & Sources \\
\hline $\begin{array}{l}\text { Resilience and sustainability have emerged as critical concepts for } \\
\text { comprehending contemporary urban dynamics and addressing } \\
\text { the issues associated with developing habitable urban futures. }\end{array}$ & 2016 & $\begin{array}{l}\text { Romero-Lankao } \\
\text { et al. [153] }\end{array}$ \\
\hline $\begin{array}{l}\text { With current demographics, urbanization, and changing climate } \\
\text { concerns, incorporating sustainability and resilience concepts into } \\
\text { urban planning becomes critical for decision-makers globally. }\end{array}$ & 2016 & $\begin{array}{l}\text { Grafakos et al. } \\
\text { [154] }\end{array}$ \\
\hline $\begin{array}{l}\text { Urban sustainability and resilience is an enticing topic of } \\
\text { regulatory and governance research, both empirical and } \\
\text { theoretical. There are a number of factors that contribute to the } \\
\text { complexity of urban sustainability and resilience management, } \\
\text { including a wide range of actors and concerns, settings, and the } \\
\text { rapid development in urban networks. }\end{array}$ & 2017 & $\begin{array}{l}\text { van der Heijden } \\
\text { [31] }\end{array}$ \\
\hline $\begin{array}{l}\text { The concepts of urban resilience and sustainability vary not just } \\
\text { in terms of the theoretical foundations but also in terms of their } \\
\text { empirical investigations. Real urban development may be } \\
\text { obtained only when it is resilient and sustainable. }\end{array}$ & 2018 & Zhang and Li [4] \\
\hline $\begin{array}{l}\text { Resilience is emerging as a paradigm of managing } \\
\text { urban sustainability. }\end{array}$ & 2021 & $\begin{array}{c}\text { Bruzzone et al. } \\
\text { [50] }\end{array}$ \\
\hline $\begin{array}{l}\text { While resilience is appealing academically, it is often ignored in } \\
\text { contemporary urban planning and architecture. A system can } \\
\text { respond to change or disruption without altering its fundamental } \\
\text { state. It is contingent upon one's capacity to adjust to } \\
\text { unprecedented and unexpected changes. }\end{array}$ & 2021 & Huq et al. [155] \\
\hline
\end{tabular}

\section{Discussion}

\subsection{Urban Resilience}

\subsubsection{Concepts of Urban Resilience}

The resilience definition has been used in various scientific ways, transforming it from a descriptive word to a normative method or "way of thinking". The normative approach mainly deals with the value judgment of the concept for its rational use. This way of thinking about how a complex system can persist when facing complexity, disruption, and change has become standard. Resilience may be positive or negative, but in academic and policy circles, "resilience thinking," and the notion of "resilient cities" have developed as normative, desirable objectives. These various interpretations of the word have resulted in many meanings and misunderstandings about what resilience is and how it applies to other important concepts. Holling [156] differentiated between static "engineering" resilience, which relates to the ability of a system to rebound back to its former state, and dynamic "ecological" resilience, which indicates preserving key roles when disturbed, by describing ecosystems as taking several stable states as an example.

\subsubsection{Key Dimensions of Urban Resilience}

Generally, there are three major components of urban resilience: adaptive, absorptive, and transformative. The holistic view of urban resilience has been presented in Figure 3.

\section{Adaptive Capacity}

Adaptive capacity is the ability to make small, deliberate changes in advance of or in response to a change in order to increase potential flexibility [8]. It is important because change is constant and unpredictable, and deliberate transformation requires time and commitment. Making necessary changes to better accommodate or respond to a changing environment is what adaptation is all about. Accepting that change is highly uncertain is an essential feature of adaptive capability. That is why adaptive capacity is all about 
adaptability and the ability to make minor improvements over time through a process of constantly adapting, learning, and innovation and the degree to which a system can alter while maintaining its purpose and structure. People's absorption ability must be increased by using local networks, access to knowledge, and good farming practices. Adaptive ability is typically demonstrated or deployed in food systems to sustain livelihoods, food production, or food access [9]. It is crucial to differentiate between adaptation ability and mitigation in light of climate change. Adaptive capacity is used to adjust to changes in growing or living environments and shocks caused by climate change. Mitigation entails deliberately mitigating the impact of climate change rather than adapting to its consequences, such as lowering pollution, reducing meat intake among meat-consuming populations, or geoengineering the atmosphere to lower $\mathrm{CO}_{2}$ concentrations.

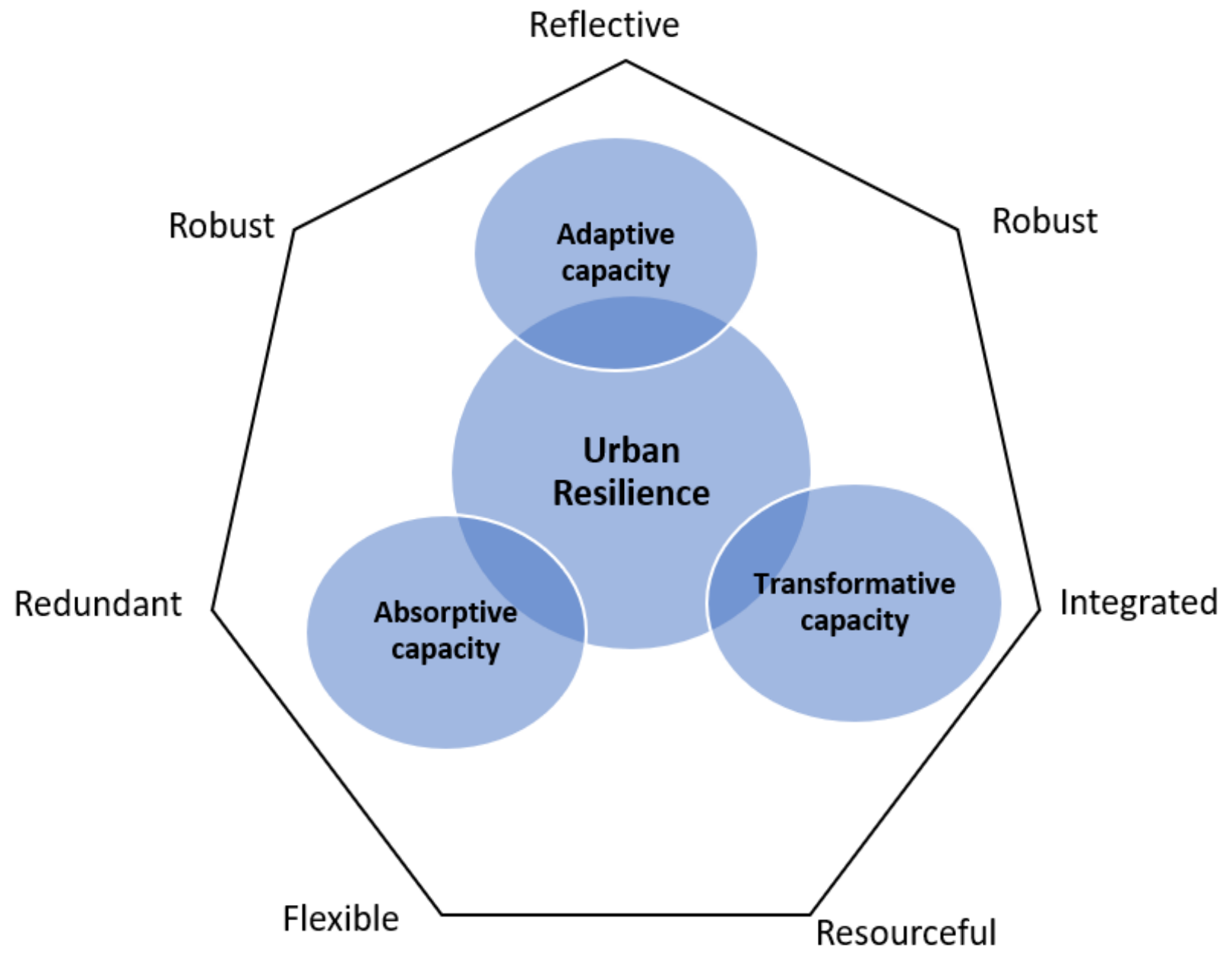

Figure 3. Key elements and nature of urban resilience.

The second important property is adaptive capability, which refers to the ability of agri-food systems to respond to extreme conditions. Within agri-food systems, for example, human systems can be able to migrate to alternative land use. People will be able to adapt to change in these situations because they can adjust their land and other resources.

\section{Absorptive Capacity}

Absorptive capacity means the ability of a system to take deliberate preventive measures and cope with established shocks and stress [8]. It is required because shocks and tension will continue to occur, such as extreme weather actions brought about by climate change, prolonged war, and natural disasters. This refers to the ability to recover from a shock. Anticipating, preparing, coping, and recovering from real, established shocks and short-term stresses are all part of the process. Absorptive capacity focuses on avoiding or 
mitigating the harmful effects of shocks on individuals, families, societies, industries, and governments [15]. Absorptive capacity also focuses on combining experiences and skills and incremental changes to external drivers. Through learning, funding, and diversifying development, it is necessary to make necessary adjustments to better handle or adapt to adverse conditions.

\section{Transformative Capacity}

Transformative capacity is the ability to implement changes to stop or reduce the causes of risk and vulnerability and ensure an equitable risk-sharing condition [8]. People living in poverty or experiencing deprivation are not unfairly burdened. Transformation can also address the root causes of risk and poverty, such as development failures or power imbalances. Transformation addresses the structural or root causes of risk and vulnerability rather than the immediate or proximate causes. It is also likely that a transition at one level would create momentum at a higher level. Increased gender justice in the home, for example, will create support for progress in the larger society. This is also known as passing a level or being at a turning point. External disasters, such as an earthquake or other catastrophes, are the most common causes of tipping points. Slow change can also lead to a leaning point when a region becomes too drought-prone for current agricultural practices [15]. These upheavals in the status quo allow reorganizing and potentially transforming inequitable and ineffective practices and systems. When the initial state is no longer bearable, a new structure is created by drastically changing its features and behavior. Transformational responses are guided by self-organization, risk management, and efficient institutions [97].

\subsubsection{Characteristics of Urban Resilience}

Urban resilience usually has seven key characteristics to protect against the vulnerability of natural hazards: reflective, redundant, robust, inclusive, integrated, resourceful, and flexible of an urban system (Figure 3).

Reflective: People and organizations learn from their mistakes through an adaptive preparation mentality that recognizes unpredictability. Rather than finding enduring solutions based on an appraisal of current shocks and stresses, they have processes in place to continually change standards based on new data.

Robust: Robust city structures are designed and maintained to withstand the effects of severe weather and prevent the city from collapsing due to the failure of a single component. A stable device anticipates system failures and builds safeguards to ensure predictability and protection [8].

Redundant: When one system element fails, other components or ways may meet critical functional requirements. For example, having several access points to various utility services of a city. Overdependence on a "fail-safe" device may reveal a fundamental deficiency of resilience.

Flexible: In response to changing circumstances, a city with flexible structures can adapt, develop, and implement alternative strategies. The decentralization of traditional infrastructure with emerging technology is favored in these systems.

Resourceful: People and organizations should invest in their ability to predict future urban developments, set goals, and organize and organize resources. A city's resource capitals can prepare it to adapt quickly to severe incidents, adjusting organizations and procedures when necessary [15].

Inclusive: Communities, especially those marginalized, are consulted and engaged as part of an inclusive approach. A city's resilience cannot be built in isolation from the rest of the world. Collective ownership and a shared vision from different groups in the city are needed for resilience [8].

Integrated: City processes, decision-making, and investments can all work together to achieve a common goal. Proof of processes that operate across various service scales can 
be found in resilient system integration. Integration necessitates a continuous feedback mechanism for data collection and response [128].

\subsection{Urban Sustainability}

\subsubsection{Concepts of Urban Sustainability}

Many scholars still largely overlook the concepts of urban sustainability and sustainable development. Before assessing urban sustainability, some scholars argue that there needs to be more consensus about what it entails. Sustainable development is impossible in an unhealthy urban environment. Consequently, environmental sustainability must also be extended to urban settings [134]. City planners, stakeholders, and players involved in the entire urban planning process should apply priorities, policies, mechanisms, and metrics for achieving urban sustainability. At the same time, proposals and targets for sustainable growth should be accomplished through policy, decision-making, and politics. Given the conditions, a substantial distinction should be made between sustainable growth and urban sustainability [109]. Urban sustainability cannot be achieved by avoiding extreme social inequality, natural resources, sustainable growth, human health, and prosperity [134]. Consequently, while sustainable growth is a global and slightly abstract aim, urban sustainability denotes events on a more specific and local scale.

\subsubsection{Urban Sustainability Dimensions \\ Environmental Sustainability}

Environmental sustainability is a basic concept of sustainability. It means that fulfilling needs might not come at the cost of the environment's efficiency and that the ecological system should be protected for future generations [147]. Incorporating environmental sustainability practices into urban management practices can reduce urban areas' vulnerability and enhance urban citizens' resilience [107]. The constant rise in emissions and depletion of resources has raised environmental conservation to a new level of urgency, demanding peoples', companies', and governments' undivided attention. As a result, citizen and stakeholder pressures are rising to implement environmentally friendly practices. Thus, sustainable practices can be positioned to deliver more value to people and enhance resilience. Environmentally sustainable activities must be addressed when urban actors implement digital transformation strategies to evolve urban development models and create compelling impacts [144]. Environmental planning and sustainability policy are essential aspects of controlling ecological resources, provisioning natural ecosystems, and ecological services.

\section{Social Sustainability}

Since most sustainability studies emphasize environmental or economic aspects, social sustainability is often overlooked. All three components of sustainability must be addressed to produce the most long-term results. Social sustainability is achieved when internal and external procedures, initiatives, constructions, and alliances actively foster present and future generations' capacity to create healthy and sustainable communities [36]. Economically sustainable societies are equal, diverse, linked, and democratic, with a high quality of life. It is a process for ensuring effective good places that promote well-being by realizing what people need from their lives and work. Social sustainability encompasses both physical and social domain indicators.

\section{Economic Sustainability}

The notion of resource planning is used to define and explain the present worth of resources as well as their potential future value in the economy. To explain the value, criteria like added value, assets and responsibilities, savings, patents, and intangible assets may be used. The term "economic sustainability" refers to a subset of the term "sustainability." It refers to how we utilize, safeguard, and maintain resources in urban management to produce long-term value through optimum use, regeneration, and recycling. [143]. To put it 
another way, we must protect scarce natural resources now for future generations to fulfill their own needs.

\subsection{Urban Resilience for Promoting Urban Sustainability}

Sustainability is considered a societal goal, but resilience is regarded as a characteristic of the urban system. The two concepts operate together as a formidable duo [153]. A city's ability to adapt and recover when confronted with adversity improves when it engages in sustainable growth initiatives. The ability to maintain human and environmental wellbeing while also guaranteeing that the well-being and capacity of locations throughout the world to be adaptive and sustainable are not harmed is achieved through this process [154].

Urban planning must change and be flexible to support sustainable growth, increase resilience, and advance remedies for current urban challenges. Many cities have already begun to apply the concepts of urban resilience and sustainability to specific areas. However, URS (urban resilience and sustainability) are not limited to a single site but rather apply across entire systems, including a diverse spectrum of resources, wastes, assets, and knowledge movements. The connections can be complicated, and the feedback systems can be indirect. Unintended implications of a restrictive definition and local application of sustainability can include 'locking in' suboptimal urban growth trajectories and degradation of sustainability elsewhere. On the other hand, new models are emerging that add value to nature's services in urban contexts. When combined with growing global cooperation among cities, they may support constructing the chains of sustainable resources.

However, while resilience and sustainability are fundamentally concerned with preserving societal health and well-being within the context of a broader framework of environmental change, there are significant differences in their emphasis and time scale, particularly in the context of urbanization. The term "sustainability" refers to the desire for long-term mutual benefit between culture and the environment [157]. Sustainability has always been an unsolidified notion that acknowledges the limitations of present knowledge and the danger involved in basing all decisions solely on the most robust empirical data. Nonetheless, it is now widely recognized that the organization and operation of a sustainable system require embedded strategies and nested tactics that can react quickly and effectively within accelerated time-scales, allowing for the recovery from dramatic system shocks while maintaining basic system integrity or, more preferably, while maintaining capacities for adaptation to changing conditions that are both engaged and undiminished [158].

\section{Conclusions}

Urbanization and natural hazards are two of the most pressing issues today. These phenomena are inextricably related and evidence of interactions with other processes. Climate change directly impacts the lives of millions of people worldwide, not only in developing countries. As a result, the effects of climate change, including floods, droughts, and hurricanes, are not evenly felt or distributed, and human social contact with climaterelated hazards necessitates further implicit consideration. This study is an initiative to clarify the concepts UR and US for genuine use. This study argues that sustainability and resilience are interconnected paradigms that highlight a system's capacity to achieve sustainable urban development. Resilience and sustainability are concerned with conserving societal health and well-being within the context of environmental change. In the rapid urbanization context, both concepts provide different meanings in their emphasis and time scales.

Sustainability remains an effective normative idea that promotes mutually beneficial relationships for society and the environment. It imposes on us the responsibility to prevent behaviors that we anticipate or believe will weaken that relationship. It is not about establishing an unattended balance but rather about tender care and awareness of our actions. Resilience has evolved as an important component of sustainability in recent years. It is concerned with recovery from individual environmental, societal, or economic 
shocks and adaptation to several occurrences or chronic challenges such as climate change. While society's persistence is the most fundamental necessity for resilience, the capacity to adapt and transform aspires to a higher degree of response. This increased resilience is the surest path to the long-term mutual advantages of sustainability. This study has also identified key indicators under three major components for addressing urban vulnerability: adaptive capacity (education, health, food, and water), absorptive capacity (community support, urban green space, protective infrastructure, and access to transportation), and transformative capacity (communication technology, multi-stakeholder collaboration, and government emergency services). In some contexts, the terms sustainability and resilience can be applied interchangeably. Resilience is also considered a major element of wider sustainability goals. It also has been praised as a new and better paradigm. This study argues that system resilience is critical for attaining sustainability in a rapidly urbanized condition. Understanding the relationship between UR and the US is deemed critical for policymakers, as seen by the development of the UN's 11th Sustainable Development Goal (SDG), which aims to make cities more inclusive, safe, resilient, and sustainable. The findings will aid in the comprehensive understanding of the dynamics of urban vulnerability, resilience, and sustainability and the measurement and management approach and help achieve a sustainable and resilient city.

Future research into the role of urban resilience in attaining urban sustainability is critical. This study has several limitations due to its nature. Firstly, this study is based on the secondary sources available in the existing literature. Secondly, the search strings retrieved only the most relevant literature, rather than retrieving all due to a wider application of urban resilience and sustainability concepts. Thirdly, this study covered a period from 1 January 2001 to 30 November 2021, rather than from the initiation of the concepts. Finally, this study emphasized only the most relevant theoretical explanation of the scholars rather than covering all to contribute to the current debate. Future studies may address this limitation by incorporating primary data for each urban resilience and sustainability indicator. As this research demonstrated, one of the primary goals of urban resilience is to improve system's adaptive, absorptive, and transformative capacity. Yet, there is no clear definition of what this entails or cost to society and the environment. Thus, future efforts to define urban resilience should investigate the causal relationship between improved citizens' capacity and the use of contemporary technology. This may provide ample space to use urban resilience practices for ensuring urban sustainability.

Author Contributions: Conceptualization, X.Z. and Y.Y.; methodology, X.Z., Y.Y. and M.N.I.S.; validation, X.Z., Y.Y., Y.L. and M.N.I.S.; data curation, X.Z., Y.Y., S.Y., Y.L. and M.N.I.S.; writingoriginal draft preparation, X.Z. and Y.Y.; writing - review and editing, X.Z., Y.Y., S.Y., Y.L. and M.N.I.S. All authors have read and agreed to the published version of the manuscript.

Funding: This research received no external funding.

Institutional Review Board Statement: Not applicable.

Informed Consent Statement: Not applicable.

Data Availability Statement: Not applicable.

Conflicts of Interest: The authors declare no conflict of interest.

Appendix A. PRISMA 2020 Checklist

\begin{tabular}{cccc}
\hline $\begin{array}{c}\text { Section } \\
\text { and Topic }\end{array}$ & $\begin{array}{c}\text { Item } \\
\text { n }\end{array}$ & Checklist Item & $\begin{array}{c}\text { Location } \\
\text { Where Item } \\
\text { Is Reported }\end{array}$ \\
\hline Title & 1 & TITLE & Page 1 \\
\hline \multicolumn{4}{c}{ Identify the report as a systematic review. } \\
\hline
\end{tabular}




\begin{tabular}{|c|c|c|c|}
\hline $\begin{array}{l}\text { Section } \\
\text { and Topic }\end{array}$ & $\begin{array}{l}\text { Item } \\
\#\end{array}$ & Checklist Item & $\begin{array}{l}\text { Location } \\
\text { Where Item } \\
\text { Is Reported }\end{array}$ \\
\hline Abstract & 2 & See the PRISMA 2020 for Abstracts checklist. & Page 1 \\
\hline \multicolumn{4}{|c|}{ INTRODUCTION } \\
\hline Rationale & 3 & $\begin{array}{c}\text { Describe the rationale for the review in the context of } \\
\text { existing knowledge. }\end{array}$ & Page 3 \\
\hline Objectives & 4 & $\begin{array}{l}\text { Provide an explicit statement of the objective(s) or } \\
\text { question(s) the review addresses. }\end{array}$ & Page 3 \\
\hline \multicolumn{4}{|c|}{ METHODS } \\
\hline $\begin{array}{l}\text { Eligibility } \\
\text { criteria }\end{array}$ & 5 & $\begin{array}{l}\text { Specify the inclusion and exclusion criteria for the review } \\
\text { and how studies were grouped for the syntheses. }\end{array}$ & Page 4 \\
\hline $\begin{array}{l}\text { Information } \\
\text { sources }\end{array}$ & 6 & $\begin{array}{l}\text { Specify all databases, registers, websites, organisations, } \\
\text { reference lists and other sources searched or consulted to } \\
\text { identify studies. Specify the date when each source was } \\
\text { last searched or consulted. }\end{array}$ & Page 4 \\
\hline $\begin{array}{l}\text { Search } \\
\text { strategy }\end{array}$ & 7 & $\begin{array}{l}\text { Present the full search strategies for all databases, registers } \\
\text { and websites, including any filters and limits used. }\end{array}$ & Page 5 \\
\hline $\begin{array}{l}\text { Selection } \\
\text { process }\end{array}$ & 8 & $\begin{array}{l}\text { Specify the methods used to decide whether a study met } \\
\text { the inclusion criteria of the review, including how many } \\
\text { reviewers screened each record and each report retrieved, } \\
\text { whether they worked independently, and if applicable, } \\
\text { details of automation tools used in the process. }\end{array}$ & Page 5 \\
\hline $\begin{array}{l}\text { Data } \\
\text { collection } \\
\text { process }\end{array}$ & 9 & $\begin{array}{l}\text { Specify the methods used to collect data from reports, } \\
\text { including how many reviewers collected data from each } \\
\text { report, whether they worked independently, any processes } \\
\text { for obtaining or confirming data from study investigators, } \\
\text { and if applicable, details of automation tools used in } \\
\text { the process. }\end{array}$ & Page 5 \\
\hline \multirow{2}{*}{ Data items } & $10 \mathrm{a}$ & $\begin{array}{l}\text { List and define all outcomes for which data were sought. } \\
\text { Specify whether all results that were compatible with each } \\
\text { outcome domain in each study were sought (e.g., for all } \\
\text { measures, time points, analyses), and if not, the methods } \\
\text { used to decide which results to collect. }\end{array}$ & Page 5 \\
\hline & $10 \mathrm{~b}$ & $\begin{array}{l}\text { List and define all other variables for which data were } \\
\text { sought (e.g., participant and intervention characteristics, } \\
\text { funding sources). Describe any assumptions made about } \\
\text { any missing or unclear information. }\end{array}$ & Page 5 \\
\hline $\begin{array}{l}\text { Study risk } \\
\text { of bias as- } \\
\text { sessment }\end{array}$ & 11 & $\begin{array}{l}\text { Specify the methods used to assess risk of bias in the } \\
\text { included studies, including details of the tool(s) used, how } \\
\text { many reviewers assessed each study and whether they } \\
\text { worked independently, and if applicable, details of } \\
\text { automation tools used in the process. }\end{array}$ & Page 5 \\
\hline $\begin{array}{c}\text { Effect } \\
\text { measures }\end{array}$ & 12 & $\begin{array}{l}\text { Specify for each outcome the effect measure(s) (e.g., risk } \\
\text { ratio, mean difference) used in the synthesis or } \\
\text { presentation of results. }\end{array}$ & Page 5 \\
\hline
\end{tabular}




\begin{tabular}{|c|c|c|c|}
\hline $\begin{array}{l}\text { Section } \\
\text { and Topic }\end{array}$ & $\begin{array}{l}\text { Item } \\
\#\end{array}$ & Checklist Item & $\begin{array}{l}\text { Location } \\
\text { Where Item } \\
\text { Is Reported }\end{array}$ \\
\hline \multirow{6}{*}{$\begin{array}{l}\text { Synthesis } \\
\text { methods }\end{array}$} & $13 a$ & $\begin{array}{l}\text { Describe the processes used to decide which studies were } \\
\text { eligible for each synthesis (e.g., tabulating the study } \\
\text { intervention characteristics and comparing against the } \\
\text { planned groups for each synthesis (item \#5)). }\end{array}$ & Page 5 \\
\hline & $13 b$ & $\begin{array}{l}\text { Describe any methods required to prepare the data for } \\
\text { presentation or synthesis, such as handling of missing } \\
\text { summary statistics, or data conversions. }\end{array}$ & Page 5 \\
\hline & $13 \mathrm{c}$ & $\begin{array}{l}\text { Describe any methods used to tabulate or visually display } \\
\text { results of individual studies and syntheses. }\end{array}$ & Page 5 \\
\hline & $13 \mathrm{~d}$ & $\begin{array}{l}\text { Describe any methods used to synthesize results and } \\
\text { provide a rationale for the choice(s). If meta-analysis was } \\
\text { performed, describe the model(s), method(s) to identify the } \\
\text { presence and extent of statistical heterogeneity, and } \\
\text { software package(s) used. }\end{array}$ & $\mathrm{N} / \mathrm{A}$ \\
\hline & $13 \mathrm{e}$ & $\begin{array}{l}\text { Describe any methods used to explore possible causes of } \\
\text { heterogeneity among study results (e.g., subgroup analysis, } \\
\text { meta-regression). }\end{array}$ & $\mathrm{N} / \mathrm{A}$ \\
\hline & $13 \mathrm{f}$ & $\begin{array}{l}\text { Describe any sensitivity analyses conducted to assess } \\
\text { robustness of the synthesized results. }\end{array}$ & $\mathrm{N} / \mathrm{A}$ \\
\hline $\begin{array}{l}\text { Reporting } \\
\text { bias assess- } \\
\text { ment }\end{array}$ & 14 & $\begin{array}{c}\text { Describe any methods used to assess risk of bias due to } \\
\text { missing results in a synthesis (arising from reporting } \\
\text { biases). }\end{array}$ & Page 5 \\
\hline \multirow[t]{2}{*}{$\begin{array}{l}\text { Certainty } \\
\text { assess- } \\
\text { ment }\end{array}$} & 15 & $\begin{array}{l}\text { Describe any methods used to assess certainty (or } \\
\text { confidence) in the body of evidence for an outcome. }\end{array}$ & Page 5 \\
\hline & & RESULTS & \\
\hline \multirow{2}{*}{$\begin{array}{l}\text { Study } \\
\text { selection }\end{array}$} & $16 \mathrm{a}$ & $\begin{array}{l}\text { Describe the results of the search and selection process, } \\
\text { from the number of records identified in the search to the } \\
\text { number of studies included in the review, ideally using a } \\
\text { flow diagram. }\end{array}$ & Page 6 \\
\hline & $16 b$ & $\begin{array}{l}\text { Cite studies that might appear to meet the inclusion } \\
\text { criteria, but which were excluded, and explain why they } \\
\text { were excluded. }\end{array}$ & Page 6 \\
\hline $\begin{array}{l}\text { Study } \\
\text { character- } \\
\text { istics }\end{array}$ & 17 & Cite each included study and present its characteristics. & Page 6 \\
\hline $\begin{array}{l}\text { Risk of } \\
\text { bias in } \\
\text { studies }\end{array}$ & 18 & Present assessments of risk of bias for each included study. & Page 6 \\
\hline $\begin{array}{l}\text { Results of } \\
\text { individual } \\
\text { studies }\end{array}$ & 19 & $\begin{array}{l}\text { For all outcomes, present, for each study: (a) summary } \\
\text { statistics for each group (where appropriate) and (b) an } \\
\text { effect estimate and its precision (e.g., confidence/credible } \\
\text { interval), ideally using structured tables or plots. }\end{array}$ & Page 7 \\
\hline
\end{tabular}




\begin{tabular}{|c|c|c|c|}
\hline $\begin{array}{l}\text { Section } \\
\text { and Topic }\end{array}$ & $\begin{array}{l}\text { Item } \\
\quad \#\end{array}$ & Checklist Item & $\begin{array}{l}\text { Location } \\
\text { Where Item } \\
\text { Is Reported }\end{array}$ \\
\hline \multirow{4}{*}{$\begin{array}{l}\text { Results of } \\
\text { syntheses }\end{array}$} & $20 \mathrm{a}$ & $\begin{array}{c}\text { For each synthesis, briefly summarise the characteristics } \\
\text { and risk of bias among contributing studies. }\end{array}$ & Page 7 \\
\hline & $20 \mathrm{~b}$ & $\begin{array}{l}\text { Present results of all statistical syntheses conducted. If } \\
\text { meta-analysis was done, present for each the summary } \\
\text { estimate and its precision (e.g., confidence/credible } \\
\text { interval) and measures of statistical heterogeneity. If } \\
\text { comparing groups, describe the direction of the effect. }\end{array}$ & Page 7 \\
\hline & $20 \mathrm{c}$ & $\begin{array}{l}\text { Present results of all investigations of possible causes of } \\
\text { heterogeneity among study results. }\end{array}$ & Page 8 \\
\hline & $20 d$ & $\begin{array}{l}\text { Present results of all sensitivity analyses conducted to } \\
\text { assess the robustness of the synthesized results. }\end{array}$ & $\mathrm{N} / \mathrm{A}$ \\
\hline $\begin{array}{l}\text { Reporting } \\
\text { biases }\end{array}$ & 21 & $\begin{array}{l}\text { Present assessments of risk of bias due to missing results } \\
\text { (arising from reporting biases) for each synthesis assessed. }\end{array}$ & Page 9 \\
\hline \multirow[t]{2}{*}{$\begin{array}{l}\text { Certainty } \\
\text { of } \\
\text { evidence }\end{array}$} & 22 & $\begin{array}{l}\text { Present assessments of certainty (or confidence) in the } \\
\text { body of evidence for each outcome assessed. }\end{array}$ & Page 9 \\
\hline & & DISCUSSION & \\
\hline \multirow{4}{*}{ Discussion } & $23 a$ & $\begin{array}{l}\text { Provide a general interpretation of the results in the } \\
\text { context of other evidence. }\end{array}$ & Page $10-18$ \\
\hline & $23 b$ & $\begin{array}{l}\text { Discuss any limitations of the evidence included in } \\
\text { the review. }\end{array}$ & Page 19 \\
\hline & $23 c$ & Discuss any limitations of the review processes used. & Page 19 \\
\hline & $23 d$ & $\begin{array}{l}\text { Discuss implications of the results for practice, policy, and } \\
\text { future research. }\end{array}$ & Page 19 \\
\hline & & OTHER INFORMATION & \\
\hline \multirow{3}{*}{$\begin{array}{l}\text { Registration } \\
\text { and } \\
\text { protocol }\end{array}$} & $24 \mathrm{a}$ & $\begin{array}{l}\text { Provide registration information for the review, including } \\
\text { register name and registration number, or state that the } \\
\text { review was not registered. }\end{array}$ & $\mathrm{N} / \mathrm{A}$ \\
\hline & $24 b$ & $\begin{array}{l}\text { Indicate where the review protocol can be accessed, or } \\
\text { state that a protocol was not prepared. }\end{array}$ & Page 5 \\
\hline & $24 \mathrm{c}$ & $\begin{array}{c}\text { Describe and explain any amendments to information } \\
\text { provided at registration or in the protocol. }\end{array}$ & $\mathrm{N} / \mathrm{A}$ \\
\hline Support & 25 & $\begin{array}{l}\text { Describe sources of financial or non-financial support for } \\
\text { the review, and the role of the funders or sponsors in the } \\
\text { review. }\end{array}$ & $\mathrm{N} / \mathrm{A}$ \\
\hline $\begin{array}{l}\text { Competing } \\
\text { interests }\end{array}$ & 26 & Declare any competing interests of review authors. & Page 19 \\
\hline $\begin{array}{l}\text { Availability } \\
\text { of data, } \\
\text { code and } \\
\text { other } \\
\text { materials }\end{array}$ & 27 & $\begin{array}{l}\text { Report which of the following are publicly available and } \\
\text { where they can be found: template data collection forms; } \\
\text { data extracted from included studies; data used for all } \\
\text { analyses; analytic code; any other materials used in the } \\
\text { review. }\end{array}$ & Page 5 \\
\hline
\end{tabular}

From [159]. For more information, visit: http:/ / www.prisma-statement.org/ accessed on 1 November 2021. 


\section{References}

1. Sarker, M.N.I.; Khatun, M.N.; Alam, G.M.; Islam, M.S. Big Data Driven Smart City: Way to Smart City Governance. In Proceedings of the 2020 International Conference on Computing and Information Technology (ICCIT-1441), Tabuk, Saudi Arabia, 9-10 September 2020; pp. 1-8.

2. Kumar, A.; Diksha; Pandey, A.C.; Khan, M.L. Urban Risk and Resilience to Climate Change and Natural Hazards. In Techniques for Disaster Risk Management and Mitigation; Wiley: Hoboken, NJ, USA, 2020; pp. 33-46.

3. Müller, A.; Reiter, J.; Weiland, U. Assessment of urban vulnerability towards floods using an indicator-based approach-a case study for Santiago de Chile. Nat. Hazards Earth Syst. Sci. 2011, 11, 2107-2123. [CrossRef]

4. Zhang, X.; Li, H. Urban resilience and urban sustainability: What we know and what do not know? Cities 2018, 72, 141-148 [CrossRef]

5. Cariolet, J.M.; Vuillet, M.; Diab, Y. Mapping urban resilience to disasters-A review. Sustain. Cities Soc. 2019, 51, 101746. [CrossRef]

6. Sharifi, A. Urban form resilience: A meso-scale analysis. Cities 2019, 93, 238-252. [CrossRef]

7. LopezDeAsiain, M.; Díaz-García, V. The Importance of the Participatory Dimension in Urban Resilience Improvement Processes. Sustainability 2020, 12, 7305. [CrossRef]

8. Sarker, M.N.I.; Wu, M.; Alam, G.M.M.G.M.; Shouse, R.C. Administrative Resilience in the Face of Natural Disasters: Empirical Evidence from Bangladesh. Pol. J. Environ. Stud. 2020, 29, 1825-1837. [CrossRef]

9. $\quad$ Sarker, M.N.I.; Wen, J.; Yang, B.; Yusufzada, S.; Huda, N.; Mahbub, F. Assessment of environmental governance in disaster vulnerability context of rural bangladesh. Growth Chang. 2021, 52, 1155-1171. [CrossRef]

10. Pirlone, F.; Spadaro, I.; Candia, S. More Resilient Cities to Face Higher Risks. The Case of Genoa. Sustainability 2020, $12,4825$. [CrossRef]

11. Fitzgibbons, J.; Mitchell, C. Just urban futures? Exploring equity in "100 Resilient Cities". World Dev. 2019, 122, 648-659. [CrossRef]

12. Redman, C.L. Should sustainability and resilience be combined or remain distinct pursuits? Ecol. Soc. 2014, 19, 37. [CrossRef]

13. Miller, T.R. Constructing sustainability science: Emerging perspectives and research trajectories. Sustain. Sci. 2013, 8, 279-293. [CrossRef]

14. Brand, F.S.; Jax, K. Resilience as a Descriptive Concept and a Boundary Object. Ecol. Soc. 2007, 12, art23. [CrossRef]

15. Wubneh, M. Urban resilience and sustainability of the city of Gondar (Ethiopia) in the face of adverse historical changes. Plan. Perspect. 2021, 36, 363-391. [CrossRef]

16. Adinyira, E.; Oteng-Seifah, S.; Adjei-Kumi, T. A Review of Urban Sustainability Assessment Methodologies Emmanuel. In Proceedings of the International Conference on Whole Life Urban Sustainability and Its Asses, Glasgow, UK, 27-29 June 2007; pp. 1-8.

17. Toli, A.M.; Murtagh, N. The Concept of Sustainability in Smart City Definitions. Front. Built Environ. 2020, 6, 77. [CrossRef]

18. Pissourios, I.A. An interdisciplinary study on indicators: A comparative review of quality-of-life, macroeconomic, environmental, welfare and sustainability indicators. Ecol. Indic. 2013, 34, 420-427. [CrossRef]

19. Tanguay, G.A.; Rajaonson, J.; Lefebvre, J.F.; Lanoie, P. Measuring the sustainability of cities: An analysis of the use of local indicators. Ecol. Indic. 2010, 10, 407-418. [CrossRef]

20. Turcu, C. Re-thinking sustainability indicators: Local perspectives of urban sustainability. J. Environ. Plan. Manag. 2013, 56, 695-719. [CrossRef]

21. Lee, Y.J.; Huang, C.M. Sustainability index for Taipei. Environ. Impact Assess. Rev. 2007, 27, 505-521. [CrossRef]

22. Moldan, B.; Janoušková, S.; Hák, T. How to understand and measure environmental sustainability: Indicators and targets. Ecol. Indic. 2012, 17, 4-13. [CrossRef]

23. Mori, K.; Christodoulou, A. Review of sustainability indices and indicators: Towards a new City Sustainability Index (CSI). Environ. Impact Assess. Rev. 2012, 32, 94-106. [CrossRef]

24. Sarker, M.N.I.; Peng, Y.; Yiran, C.; Shouse, R.C. Disaster resilience through big data: Way to environmental sustainability. Int. J. Disaster Risk Reduct. 2020, 51, 101769. [CrossRef]

25. McGill, R. Urban resilience-An urban management perspective. J. Urban Manag. 2020, 9, 372-381. [CrossRef]

26. Monstadt, J.; Schmidt, M. Urban resilience in the making? The governance of critical infrastructures in German cities. Urban Stud. 2019, 56, 2353-2371. [CrossRef]

27. da Silva, C.A.; dos Santos, E.A.; Maier, S.M.; da Rosa, F.S. Urban resilience and sustainable development policies. Rev. Gestão 2019, 27, 61-78. [CrossRef]

28. Meerow, S.; Stults, M. Comparing conceptualizations of urban climate resilience in theory and practice. Sustainability $2016,8,701$. [CrossRef]

29. Holling, C.S. Resilience and Stability of Ecological Systems. Annu. Rev. Ecol. Syst. 1973, 4, 1-23. [CrossRef]

30. Meerow, S.; Newell, J.P.; Stults, M. Defining urban resilience: A review. Landsc. Urban Plan. 2016, 147, 38-49. [CrossRef]

31. van der Heijden, J. Urban sustainability and resilience. In Regulatory Theory; ANU Press: Canberra, Australia, 2017; pp. 725-740. 
32. Weichselgartner, J.; Kelman, I. Geographies of resilience: Challenges and opportunities of a descriptive concept. Prog. Hum. Geogr. 2015, 39, 249-267. [CrossRef]

33. Fabbricatti, K.; Boissenin, L.; Citoni, M. Heritage Community Resilience: Towards new approaches for urban resilience and sustainability. City Territ. Archit. 2020, 7, 17. [CrossRef]

34. Meerow, S.; Newell, J.P. Urban resilience for whom, what, when, where, and why? Urban Geogr. 2019, 40, 309-329. [CrossRef]

35. Bibri, S.E. Data-driven smart sustainable cities of the future: An evidence synthesis approach to a comprehensive state-of-the-art literature review. Sustain. Future 2021, 3, 100047. [CrossRef]

36. Bibri, S.E. Advances in the Leading Paradigms of Urbanism and Their Amalgamation: Compact Cities, Eco-Cities, and Data-Driven Smart Cities; Springer Nature: Berlin/Heidelberg, Germany, 2020; ISBN 9783030417451.

37. Feroz, A.K.; Zo, H.; Chiravuri, A. Digital Transformation and Environmental Sustainability: A Review and Research Agenda. Sustainability 2021, 13, 1530. [CrossRef]

38. Billger, M.; Thuvander, L.; Wästberg, B.S. In search of visualization challenges: The development and implementation of visualization tools for supporting dialogue in urban planning processes. Environ. Plan. B Urban Anal. City Sci. 2017, 44, 1012-1035. [CrossRef]

39. Bibri, S.E. Compact urbanism and the synergic potential of its integration with data-driven smart urbanism : An extensive interdisciplinary literature review. Land Use Policy 2020, 97, 104703. [CrossRef]

40. Moher, D.; Liberati, A.; Tetzlaff, J.; Altman, D.G. Preferred Reporting Items for Systematic Reviews and Meta-Analyses: The PRISMA Statement. PLoS Med. 2009, 6, e1000097. [CrossRef]

41. Ateş, M.; Erinsel Önder, D. A local smart city approach in the context of smart environment and urban resilience. Int. J. Disaster Resil. Built Environ. 2021, 19-20. [CrossRef]

42. Acuti, D.; Bellucci, M.; Manetti, G. Company disclosures concerning the resilience of cities from the Sustainable Development Goals (SDGs) perspective. Cities 2020, 99, 102608. [CrossRef]

43. Cloete, C.E. Assessing urban resilience. WIT Trans. Inf. Commun. Technol. 2012, 44, 341-351. [CrossRef]

44. Ahern, J. From fail-safe to safe-to-fail: Sustainability and resilience in the new urban world. Landsc. Urban Plan. 2011, 100, 341-343. [CrossRef]

45. Angheloiu, C.; Tennant, M. Urban futures: Systemic or system changing interventions? A literature review using Meadows' leverage points as analytical framework. Cities 2020, 104, 102808. [CrossRef]

46. Benito del Pozo, P.; López-González, A. Urban Resilience and the Alternative Economy: A Methodological Approach Applied To Northern Spain*. Geogr. Rev. 2020, 110, 322-340. [CrossRef]

47. Bixler, R.P.; Lieberknecht, K.; Atshan, S.; Zutz, C.P.; Richter, S.M.; Belaire, J.A. Reframing urban governance for resilience implementation: The role of network closure and other insights from a network approach. Cities 2020, 103, 102726. [CrossRef]

48. Borie, M.; Pelling, M.; Ziervogel, G.; Hyams, K. Mapping narratives of urban resilience in the global south. Glob. Environ. Chang. 2019, 54, 203-213. [CrossRef]

49. Bristow, D.N.; Mohareb, E.A. From the urban metabolism to the urban immune system. J. Ind. Ecol. 2020, 24, 300-312. [CrossRef]

50. Bruzzone, M.; Dameri, R.P.; Demartini, P. Resilience reporting for sustainable development in cities. Sustainability 2021, 13, 7824. [CrossRef]

51. Chelleri, L. From the «Resilient city» to urban resilience. a review essay on understanding and integrating the resilience perspective for urban systems. Doc. D'analisi Geogr. 2012, 58, 287-306. [CrossRef]

52. Chelleri, L.; Baravikova, A. Understandings of urban resilience meanings and principles across Europe. Cities 2021, 108,102985 [CrossRef]

53. Chelleri, L.; Waters, J.J.; Olazabal, M.; Minucci, G. Resilience trade-offs: Addressing multiple scales and temporal aspects of urban resilience. Environ. Urban. 2015, 27, 181-198. [CrossRef]

54. Collier, M.J.; Nedović-Budić, Z.; Aerts, J.; Connop, S.; Foley, D.; Foley, K.; Newport, D.; McQuaid, S.; Slaev, A.; Verburg, P. Transitioning to resilience and sustainability in urban communities. Cities 2013, 32, S21-S28. [CrossRef]

55. Cui, J.; Lin, D. Utilisation of underground pedestrian systems for urban sustainability. Tunn. Undergr. Space Technol. 2016, 55, 194-204. [CrossRef]

56. Cutini, V.; Pezzica, C. Street network resilience put to test: The dramatic crash of Genoa and Bologna bridges. Sustainability 2020, 12, 4706. [CrossRef]

57. Davidson, K.; Nguyen, T.M.P.; Beilin, R.; Briggs, J. The emerging addition of resilience as a component of sustainability in urban policy. Cities 2019, 92, 1-9. [CrossRef]

58. Delgado-Ramos, G.C.; Guibrunet, L. Assessing the ecological dimension of urban resilience and sustainability. Int. J. Urban Sustain. Dev. 2017, 9, 151-169. [CrossRef]

59. Han, S.; Sim, J.; Kwon, Y. Recognition Changes of the Concept of Urban Resilience: Moderating Effects of COVID-19 Pandemic. Land 2021, 10, 1099. [CrossRef]

60. Ho, H.C.; Lin, S.W.; Lee, H.Y.; Huang, C.C. Evaluation of a multi-objective genetic algorithm for low impact development in an Overcrowded City. Water 2019, 11, 2010. [CrossRef] 
61. Karabakan, B.; Mert, Y. Measuring the Green Infrastructure Resilience in Turkey. Chin. J. Urban Environ. Stud. 2021, 9, $2021-2022$. [CrossRef]

62. Lehmann, S. Growing biodiverse urban futures: Renaturalization and rewilding as strategies to strengthen urban resilience. Sustainability 2021, 13, 2932. [CrossRef]

63. Liu, H.Y.; Jay, M.; Chen, X. The role of nature-based solutions for improving environmental quality, health and well-being. Sustainability 2021, 13, 10950. [CrossRef]

64. Liu, S.C.; Peng, F.L.; Qiao, Y.K.; Zhang, J.B. Evaluating disaster prevention benefits of underground space from the perspective of urban resilience. Int. J. Disaster Risk Reduct. 2021, 58, 102206. [CrossRef]

65. Marin, J. Global resilience models and territories of the South. A critical review. Int. J. Disaster Risk Reduct. 2021, 66, 102541. [CrossRef]

66. McGrail, S.; Idil Gaziulusoy, A.; Twomey, P. Framing processes in the envisioning of low-carbon, resilient cities: Results from two visioning exercises. Sustainability 2015, 7, 8649-8683. [CrossRef]

67. Meyer, N.; Auriacombe, C. Good urban governance and city resilience: An afrocentric approach to sustainable development. Sustainability 2019, 11, 5514. [CrossRef]

68. Muñoz-Erickson, T.A.; Meerow, S.; Hobbins, R.; Cook, E.; Iwaniec, D.M.; Berbés-Blázquez, M.; Grimm, N.B.; Barnett, A.; Cordero, J.; Gim, C.; et al. Beyond bouncing back? Comparing and contesting urban resilience frames in US and Latin American contexts. Landsc. Urban Plan. 2021, 214, 104173. [CrossRef]

69. Peyroux, E. Discourse of Urban Resilience and "Inclusive Development" in the Johannesburg Growth and Development Strategy 2040. Eur. J. Dev. Res. 2015, 27, 560-573. [CrossRef]

70. Schlör, H.; Venghaus, S.; Hake, J.F. The FEW-Nexus city index-Measuring urban resilience. Appl. Energy 2018, 210, 382-392. [CrossRef]

71. Shamout, S.; Boarin, P.; Wilkinson, S. The shift from sustainability to resilience as a driver for policy change: A policy analysis for more resilient and sustainable cities in Jordan. Sustain. Prod. Consum. 2021, 25, 285-298. [CrossRef]

72. Sharifi, A. Resilient urban forms: A macro-scale analysis. Cities 2019, 85, 1-14. [CrossRef]

73. Sharifi, A.; Allam, Z. On the taxonomy of smart city indicators and their alignment with sustainability and resilience. Environ. Plan. B Urban Anal. City Sci. 2021, 239980832110587. [CrossRef]

74. Sharifi, A.; Chelleri, L.; Fox-Lent, C.; Grafakos, S.; Pathak, M.; Olazabal, M.; Moloney, S.; Yumagulova, L.; Yamagata, Y. Conceptualizing dimensions and characteristics of urban resilience: Insights from a co-design process. Sustainability 2017, 9, 1032. [CrossRef]

75. Smith, G.; Nandwani, D.; Kankarla, V. Facilitating resilient rural-to-urban sustainable agriculture and rural communities. Int. J. Sustain. Dev. World Ecol. 2017, 24, 485-501. [CrossRef]

76. Spaans, M.; Waterhout, B. Building up resilience in cities worldwide-Rotterdam as participant in the 100 Resilient Cities Programme. Cities 2017, 61, 109-116. [CrossRef]

77. Stumpp, E.M. New in town? On resilience and "Resilient Cities". Cities 2013, 32, 164-166. [CrossRef]

78. Suárez, M.; Gómez-Baggethun, E.; Benayas, J.; Tilbury, D. Towards an urban resilience index: A case study in 50 Spanish cities. Sustainability 2016, 8, 774. [CrossRef]

79. Toubin, M.; Laganier, R.; Diab, Y.; Serre, D. Improving the Conditions for Urban Resilience through Collaborative Learning of Parisian Urban Services. J. Urban Plan. Dev. 2015, 141, 05014021. [CrossRef]

80. Tzioutziou, A.; Xenidis, Y. A study on the integration of resilience and smart city concepts in urban systems. Infrastructures 2021, 6, 24. [CrossRef]

81. Wardekker, A. Contrasting the framing of urban climate resilience. Sustain. Cities Soc. 2021, 75, 103258. [CrossRef]

82. van Eck, N.J.; Waltman, L. Software survey: VOSviewer, a computer program for bibliometric mapping. Scientometrics 2010, 84, 523-538. [CrossRef]

83. Godschalk, D.R. Urban Hazard Mitigation: Creating Resilient Cities. Nat. Hazards Rev. 2003, 4, 136-143. [CrossRef]

84. Pickett, S.T.A.; Cadenasso, M.L.; Grove, J.M. Resilient cities: Meaning, models, and metaphor for integrating the ecological, socio-economic, and planning realms. Landsc. Urban Plan. 2004, 69, 369-384. [CrossRef]

85. Campanella, T.J. Urban resilience and the recovery of new orleans. J. Am. Plan. Assoc. 2006, 72, 141-146. [CrossRef]

86. IPCC. Climate Change 2007: Impacts, Adaptation and Vulnerability; Cambridge University Press: New York, NY, USA, 2007.

87. Alberti, M.; Marzluff, J.M.; Shulenberger, E.; Bradley, G.; Ryan, C.; Zumbrunnen, C. Integrating humans into ecology: Opportunities and challenges for studying urban ecosystems. Urban Ecol. Int. Perspect. Interact. Hum. Nat. 2008, 53, 143-158. [CrossRef]

88. Lamond, J.E.; Proverbs, D.G. Resilience to flooding: Lessons from international comparison. Proc. Inst. Civ. Eng. Urban Des. Plan. 2009, 162, 63-70. [CrossRef]

89. Wardekker, J.A.; de Jong, A.; Knoop, J.M.; van der Sluijs, J.P. Operationalising a resilience approach to adapting an urban delta to uncertain climate changes. Technol. Forecast. Soc. Chang. 2010, 77, 987-998. [CrossRef]

90. Ernstson, H.; Van Der Leeuw, S.E.; Redman, C.L.; Meffert, D.J.; Davis, G.; Alfsen, C.; Elmqvist, T. Urban transitions: On urban resilience and human-dominated ecosystems. Ambio 2010, 39, 531-545. [CrossRef] [PubMed] 
91. Leichenko, R. Climate change and urban resilience. Curr. Opin. Environ. Sustain. 2011, 3, 164-168. [CrossRef]

92. Romero Lankao, P.; Qin, H. Conceptualizing urban vulnerability to global climate and environmental change. Curr. Opin. Environ. Sustain. 2011, 3, 142-149. [CrossRef]

93. Tyler, S.; Moench, M. A framework for urban climate resilience. Clim. Dev. 2012, 4, 311-326. [CrossRef]

94. Liao, K.H. A theory on urban resilience to floods-A basis for alternative planning practices. Ecol. Soc. 2012, 17, 48. [CrossRef]

95. Henstra, D. Toward the climate-resilient city: Extreme weather and urban climate adaptation policies in two Canadian provinces. J. Comp. Policy Anal. Res. Pract. 2012, 14, 175-194. [CrossRef]

96. Wamsler, C.; Brink, E.; Rivera, C. Planning for climate change in urban areas: From theory to practice. J. Clean. Prod. 2013, 50, 68-81. [CrossRef]

97. Coaffee, J. Towards Next-Generation Urban Resilience in Planning Practice: From Securitization to Integrated Place Making. Plan. Pract. Res. 2013, 28, 323-339. [CrossRef]

98. Desouza, K.C.; Flanery, T.H. Designing, planning, and managing resilient cities: A conceptual framework. Cities 2013, 35, 89-99. [CrossRef]

99. Lu, P.; Stead, D. Understanding the notion of resilience in spatial planning: A case study of Rotterdam, The Netherlands. Cities 2013, 35, 200-212. [CrossRef]

100. Thornbush, M.; Golubchikov, O.; Bouzarovski, S. Sustainable cities targeted by combined mitigation-adaptation efforts for future-proofing. Sustain. Cities Soc. 2013, 9, 1-9. [CrossRef]

101. Wagner, I.; Breil, P. The role of ecohydrology in creating more resilient cities. Ecohydrol. Hydrobiol. 2013, 13, 113-134. [CrossRef]

102. Wilson, G.A. Community resilience, policy corridors and the policy challenge. Land Use Policy 2013, 31, 298-310. [CrossRef]

103. ADB. Urban Climate Change Resilience: A Synopsis; Asian Development Bank Manila: Metro Manila, Philippines, 2014.

104. Bahadur, A.V.; Thornton, H. Analysing urban resilience: A reality check for a fledgling canon. Int. J. Urban Sustain. Dev. 2015, 7, 196-212. [CrossRef]

105. HN-Habitat. Trends in Urban Resilience 2017; United Nations Human Settlements Programme (UN-Habitat): Nairobi, Kenya, 2017; ISBN 9789211327434.

106. Eastaway, M.P.; Støa, E. Dimensions of housing and urban sustainability. J. Hous. Built Environ. 2004, 19, 1-5. [CrossRef]

107. Schwegler, C. Understanding urban sustainability through newspaper discourse: A look at Germany. J. Environ. Stud. Sci. 2015, 5, 11-20. [CrossRef]

108. Verma, P.; Raghubanshi, A.S. Urban sustainability indicators: Challenges and opportunities. Ecol. Indic. 2018, 93, 282-291. [CrossRef]

109. Wu, J. Urban ecology and sustainability: The state-of-the-science and future directions. Landsc. Urban Plan. 2014, 125, $209-221$. [CrossRef]

110. Russo, A.; Cirella, G.T. Urban Sustainability: Integrating Ecology in City Design and Planning; Springer: Singapore, 2020; ISBN 9789811530494

111. Moench, M. Experiences applying the climate resilience framework: Linking theory with practice. Dev. Pract. 2014, 24, $447-464$. [CrossRef]

112. Cobbinah, P.B. Urban resilience in climate change hotspot. Land Use Policy 2021, 100, 104948. [CrossRef]

113. Leitner, H.; Sheppard, E.; Webber, S.; Colven, E. Globalizing urban resilience. Urban Geogr. 2018, 39, 1276-1284. [CrossRef]

114. Davoudi, S.; Brooks, E.; Mehmood, A. Evolutionary Resilience and Strategies for Climate Adaptation Evolutionary Resilience and Strategies for Climate Adaptation. Plan. Pract. Res. 2013, 28, 307-322. [CrossRef]

115. Malone, E.L. Vulnerability and Resilience in the Face of Climate Change: Current Research and Needs for Population Information; Batelle: Washington, DC, USA, 2009.

116. Panampitiya, G. A Review of the Concept of Urban Fragility and Urban Resilience; Vidyalankara Press: Kelaniya, Sri Lanka, 2021.

117. Ribeiro, P.J.G.; Pena Jardim Gonçalves, L.A. Urban resilience: A conceptual framework. Sustain. Cities Soc. $2019,50,101625$. [CrossRef]

118. Molavi, M. Meauring Urban Resilence To Natural Hazards. TeMA J. Land Use Mobil. Environ. 2018, 11, $195-212$.

119. Brown, A.; Dayal, A.; Rumbaitis Del Rio, C. From practice to theory: Emerging lessons from Asia for building urban climate change resilience. Environ. Urban. 2012, 24, 531-556. [CrossRef]

120. Reischl, C.; Rauter, R.; Posch, A. Urban vulnerability and adaptation to heatwaves: A case study of Graz (Austria). Clim. Policy 2018, 18, 63-75. [CrossRef]

121. Nagenborg, M. Urban resilience and distributive justice. Sustain. Resilient Infrastruct. 2019, 4, 103-111. [CrossRef]

122. Frantzeskaki, N.; McPhearson, T.; Collier, M.J.; Kendal, D.; Bulkeley, H.; Dumitru, A.; Walsh, C.; Noble, K.; Van Wyk, E.; Ordóñez, C.; et al. Nature-based solutions for urban climate change adaptation: Linking science, policy, and practice communities for evidence-based decision-making. Bioscience 2019, 69, 455-466. [CrossRef]

123. Kim, D.; Lim, U. Urban resilience in climate change adaptation: A conceptual framework. Sustainability 2016, 8, 405. [CrossRef]

124. Heinzlef, C.; Serre, D. Urban resilience: From a limited urban engineering vision to a more global comprehensive and long-term implementation. Water Secur. 2020, 11, 100075. [CrossRef] 
125. Fang, C.; Wang, Y.; Fang, J. A comprehensive assessment of urban vulnerability and its spatial differentiation in China. J. Geogr. Sci. 2016, 26, 153-170. [CrossRef]

126. Ciumasu, I.M. A coordination lattice model for building urban resilience. In Proceedings of the International ISCRAM Conference, Rochester, NY, USA, 20-23 May 2018; pp. 419-427.

127. Carter, J.G.; Cavan, G.; Connelly, A.; Guy, S.; Handley, J.; Kazmierczak, A. Climate change and the city: Building capacity for urban adaptation. Prog. Plan. 2015, 95, 1-66. [CrossRef]

128. Bahadur, A.; Tanner, T. Transformational resilience thinking: Putting people, power and politics at the heart of urban climate resilience. Environ. Urban. 2014, 26, 200-214. [CrossRef]

129. Serrano-lópez, R.; Linares-unamunzaga, A.; Muñoz, C.; Emeterio, S. Urban sustainable mobility and planning policies. A Spanish mid-sized city case. Cities 2019, 95, 102356. [CrossRef]

130. Sta, H. Ben Quality and the efficiency of data in "Smart-Cities". Future Gener. Comput. Syst. 2017, 74, 409-416. [CrossRef]

131. Colding, J.; Barthel, S. An urban ecology critique on the "Smart City" model. J. Clean. Prod. 2017, 164, 95-101. [CrossRef]

132. Ahvenniemi, H.; Huovila, A.; Pinto-Seppä, I.; Airaksinen, M. What are the differences between sustainable and smart cities? Cities 2017, 60, 234-245. [CrossRef]

133. Maurya, S.P.; Singh, P.K.; Ohri, A.; Singh, R. Identification of indicators for sustainable urban water development planning. Ecol. Indic. 2020, 108, 105691. [CrossRef]

134. Magee, L.; Scerri, A.; James, P.; Thom, J.A.; Padgham, L.; Hickmott, S.; Deng, H.; Cahill, F.; Generating, C.; Profile, S.; et al. Urban Sustainability in Theory and Practice Circles of Sustainability; Routledge: Abingdon-on-Thames, UK, 2013 ; ISBN 9781138025721.

135. Bibri, S.E. The IoT for smart sustainable cities of the future: An analytical framework for sensor-based big data applications for environmental sustainability. Sustain. Cities Soc. 2018, 38, 230-253. [CrossRef]

136. Kong, L.; Liu, Z.; Wu, J. A systematic review of big data-based urban sustainability research: State-of-the-science and future directions. J. Clean. Prod. 2020, 273, 123142. [CrossRef]

137. Zhang, D.; Pan, S.L.; Yu, J.; Liu, W. Orchestrating big data analytics capability for sustainability: A study of air pollution management in China. Inf. Manag. 2019, 103231. [CrossRef]

138. Allen, B.; Tamindael, L.E.; Bickerton, S.H.; Cho, W. Does citizen coproduction lead to better urban services in smart cities projects? An empirical study on e-participation in a mobile big data platform. Gov. Inf. Q. 2020, 37, 101412. [CrossRef]

139. Haapio, A. Towards sustainable urban communities. Environ. Impact Assess. Rev. 2012, 32, 165-169. [CrossRef]

140. Reisi, M.; Sabri, S.; Agunbiade, M.; Rajabifard, A.; Chen, Y.; Kalantari, M.; Keshtiarast, A.; Li, Y. Transport sustainability indicators for an enhanced urban analytics data infrastructure. Sustain. Cities Soc. 2020, 59, 102095. [CrossRef]

141. Liang, J.; Xie, Y.; Sha, Z.; Zhou, A. Computers, Environment and Urban Systems Modeling urban growth sustainability in the cloud by augmenting Google Earth Engine (GEE). Comput. Environ. Urban Syst. 2020, 84, 101542. [CrossRef]

142. Pan, Y.; Tian, Y.; Liu, X.; Gu, D.; Hua, G. Urban Big Data and the Development of City Intelligence. Engineering 2016, 2, 171-178. [CrossRef]

143. Anejionu, O.C.D.; Thakuriah, P.V.; McHugh, A.; Sun, Y.; McArthur, D.; Mason, P.; Walpole, R. Spatial urban data system: A cloud-enabled big data infrastructure for social and economic urban analytics. Future Gener. Comput. Syst. 2019, 98, 456-473. [CrossRef]

144. Ilieva, R.T.; McPhearson, T. Social-media data for urban sustainability. Nat. Sustain. 2018, 1, 553-565. [CrossRef]

145. Zhang, J.; He, S. Smart technologies and urban life: A behavioral and social perspective. Sustain. Cities Soc. 2020, 63, 102460. [CrossRef]

146. Andronie, M.; Lăzăroiu, G.; Iatagan, M.; Hurloiu, I.; Dijmărescu, I. Sustainable Cyber-Physical Production Systems in Big Data-Driven Smart Urban Economy: A Systematic Literature Review. Sustainability 2021, 13, 751. [CrossRef]

147. Huang, B.; Wang, J. Big spatial data for urban and environmental sustainability. Geo-Spat. Inf. Sci. 2020, 23, 125-140. [CrossRef]

148. Folke, C.; Carpenter, S.; Elmqvist, T.; Gunderson, L.; Holling, C.S.; Walker, B. Resilience and sustainable development: Building adaptive capacity in a world of transformations. Ambio 2002, 31, 437-440. [CrossRef]

149. Friend, R.; Moench, M. What is the purpose of urban climate resilience? Implications for addressing poverty and vulnerability. Urban Clim. 2013, 6, 98-113. [CrossRef]

150. Gallopín, G.C. Linkages between vulnerability, resilience, and adaptive capacity. Glob. Environ. Chang. 2006, 16, 293-303. [CrossRef]

151. Elmqvist, T. Urban Resilience and Sustainability, Two Sides of the Same Coin? Stockholm Resilience Centre: Stockholm, Sweden, 2014.

152. Trundle, A.; Horne, R.E.; Fien, J.; Judson, E.P. Urban resilience for sustainability. In Sustainability Citizenship in Cities: Theory and Practice; Routledge: Abingdon-on-Thames, UK, 2016; pp. 1-242.

153. Romero-Lankao, P.; Gnatz, D.M.; Wilhelmi, O.; Hayden, M. Urban sustainability and resilience: From theory to practice. Sustainability 2016, 8, 1224. [CrossRef]

154. Grafakos, S.; Gianoli, A.; Tsatsou, A. Towards the development of an integrated sustainability and resilience benefits assessment framework of urban green growth interventions. Sustainability 2016, 8, 461. [CrossRef]

155. Huq, M.E.; Sarker, M.N.I.; Prasad, R.; Kormoker, T.; Hossain, M.A.; Rahman, M.M.; Al Dughairi, A.A. Resilience for Disaster Management: Opportunities and Challenges. In Climate Vulnerability and Resilience in the Global South; Springer International Publishing: New York, NY, USA, 2021; pp. 425-442, ISBN 9783030772598. 
156. Holling, C.S. Understanding the Complexity of Economic, Ecological, and Social Systems. Ecosystems 2001, 4, 390-405. [CrossRef]

157. Krellenberg, K.; Bergsträßer, H.; Bykova, D.; Kress, N.; Tyndall, K. Urban sustainability strategies guided by the SDGs-A tale of four cities. Sustainability 2019, 11, 1116. [CrossRef]

158. Rus, K.; Kilar, V.; Koren, D. Resilience assessment of complex urban systems to natural disasters: A new literature review. Int. J. Disaster Risk Reduct. 2018, 31, 311-330. [CrossRef]

159. Page, M.J.; McKenzie, J.E.; Bossuyt, P.M.; Boutron, I.; Hoffmann, T.C.; Mulrow, C.D.; Shamseer, L.; Tetzlaff, J.M.; Akl, E.A.; Brennan, S.E.; et al. The PRISMA 2020 statement: An updated guideline for reporting systematic reviews. BMJ 2021, $372,71$. [CrossRef] [PubMed] 